\title{
Patrimônios mundiais em contextos nacionais distintos: construindo paralelos entre Brasil e Portugal através dos casos de São Miguel das Missões e do Centro Histórico de Évora'
}

World Heritage in distinct national contexts: building parallels between Brazil and Portugal through the cases of São Miguel das Missões and the Historical Centre of Évora

\author{
DARLAN DE MAMANN MARCHI \\ Universidade Federal de Pelotas / Pelotas, RS, Brasil
}

\section{MARIA LETICIA MAZZUCCHI FERREIRA ${ }^{3}$}

Universidade Federal de Pelotas / Pelotas, RS, Brasil

RESUMO: As ruínas da missão jesuítico-guarani de São Miguel das Missões no Rio Grande do Sul, Brasil, e o Centro Histórico de Évora, Portugal, foram inscritos na lista do patrimônio mundial em 1983 e 1986, respectivamente. Neste artigo busca-se analisar em paralelo as patrimonializações de Évora e São Miguel, uma vez que as duas localidades há décadas já eram consideradas referências de políticas patrimoniais em seus países. Centra-se a atenção, porém, no contexto que levou à inscrição dos elementos materiais das cidades na lista da Organização das Nações Unidas Para a Educação, a Ciência e a Cultura, compreendendo o marco temporal dos anos 1980. Existem desafios comuns na gestão desses patrimônios, que, para além de insucessos ou exemplos de boas práticas, representam o tensionamento entre as trajetórias internas da construção dos processos patrimoniais e a patrimonialização em escala mundial.

PALAVRAS-CHAVE: Processos patrimoniais. Patrimônio mundial. Unesco. Comunidades.

\begin{abstract}
1. Este trabalho foi realizado com apoio do Conselho Nacional de Desenvolvimento Científico e Tecnológico (CNPq), por meio de bolsa de doutorado sanduíche no exterior na Faculdade de Ciências Sociais e Humanas da Universidade Nova de Lisboa.

2. Doutor em Memória Social e Patrimônio Cultural pela Universidade Federal de Pelotas (UFPel). Pós-doutorando em Memória Social e Patrimônio Cultural (PPGMP/UFPel), com apoio da Fundação de Amparo à Pesquisa do Estado do Rio Grande do Sul (Fapergs) e da Coordenação de Aperfeiçoamento de Pessoal de Nível Superior (Capes). E-mail: $<$ darlanmarchi@gmail.com>.

3. Professora adjunta do Instituto de Ciências Humanas e do Programa de Pós-Graduação em Memória Social e Patrimônio Cultural da Universidade Federal de Pelotas (PPGMP/UFPel). E-mail: <leticiamazzucchi@ gmail.com $>$.
\end{abstract}


ABSTRACT: The ruins of Jesuit Missions of the Guaranis in São Miguel das Missões, in the Brazilian state of Rio Grande do Sul, and the Historic Centre of Évora, Portugal, were inscribed in the World Heritage List in 1983 and 1986, respectively. This article analyzes and draws parallels between the heritagization processes of Évora and São Miguel, since both locations were already considered references in terms of heritage policies in their countries for decades. However, this article focuses on the context that led to the inscription of the material elements of these cities in the United Nations Educational, Scientific and Cultural Organization list, considering the 1980s and its specificities. There are challenges in common in regard to the management of both heritages, which go beyond failures or examples of good practices, but represent the conflicts between the two distinct paths of building heritage processes within the country and in worldwide scale.

KEYWORDS: Heritage processes. World Heritage. Unesco. Communities.

\section{CONSIDERAÇÕES INICIAIS}

As cidades de Évora e São Miguel das Missões constituem, no contexto português e no brasileiro, referências da história das políticas patrimoniais. As duas localidades são paradigmáticas da tradição patrimonial de suas nações. No caso de Évora, o passado milenar refletido nos vestígios romanos e medievais, desde o século XIX, compôs as primeiras referências materiais preservadas no espaço público e na paisagem da cidade. No que se refere a São Miguel das Missões, foi apenas nos anos 1920 que ocorreram as primeiras intervenções de caráter patrimonial, a despeito de séculos de negligência e abandono nos quais estavam mergulhadas as ruínas de uma das reduções jesuítico-guarani que se desenvolveram na região entre os séculos XVII e XVIII.

A aproximação proposta entre dois sítios do patrimônio mundial busca similaridades no que se refere aos efeitos e impactos da patrimonialização, ao mesmo tempo que resguarda as particularidades referentes aos contextos nacionais nos quais se encontram. Dentre as perguntas que nos levaram a analisar esses dois sítios, está a tentativa de perceber se os efeitos da patrimonialização, proposta 
pela Organização das Nações Unidas para a Educação, a Ciência e a Cultura (Unesco), ao introduzir um modelo organizacional próprio cujos representantes são os escritórios técnicos locais, padroniza relações e comportamentos do local perante uma instância que tende ao global. Outra pergunta que se impõe é sobre os efeitos da presença da Unesco nesses sítios do patrimônio mundial, buscando-se identificar se a visibilidade dos órgãos de preservação no espaço público (escritórios, expertises) corresponde ao reconhecimento dessa presença pelos nativos.

Nos dois casos em análise - Évora e São Miguel - é possível observar que a visão de patrimônio que se impunha era associada às obras históricas monumentais: em se tratando de Évora, o Templo Romano, ${ }^{4}$ reabilitado ao seu estado de ruína-monumento ainda na década de 1870; e em São Miguel, a fachada em ruína da igreja do povoado jesuítico-guarani, cujo restauro também a monumentalizou na paisagem como elemento representativo, em um primeiro momento, do trabalho dos missionários. Nas gravuras do século XIX de ambos os monumentos observa-se a inspiração no pitoresco, nas narrativas de viagem e no olhar romântico que precederam as primeiras teorias que definiriam as intervenções de restauro. ${ }^{5}$

A imprensa portuguesa, ainda na segunda metade do século XIX, auxiliou a popularização da ideia de monumento, no fluxo do que ocorria em outros lugares da Europa. Explorando a ideia do pitoresco, as publicações da época utilizavamse da iconografia e da literatura. Assim como na França com Victor Hugo, em Portugal, segundo Lúcia Rosas, ${ }^{6}$ os literatos oitocentistas Alexandre Herculano e Almeida Garrett, nas revistas que circulavam pelo país, destacaram em seus textos temas referentes às artes e aos estilos arquitetônicos, saindo em defesa dos monumentos históricos e nacionais.

Em São Miguel das Missões, diversos viajantes passaram pela localidade no século XIX, tais como Auguste Saint-Hilaire, Alfred Demersay, Nicolau Dreys, Arsène Isabelle, Roberto Avé-Lallemant, descrevendo e lamentando o estado de degradação do antigo povoado jesuítico-guarani. Mesmo distante de qualquer intencionalidade de reconhecimento simbólico oficial das ruínas do antigo povoado por parte do Estado brasileiro, os registros desses viajantes já acrescentavam um sentido de valor sobre o lugar e podem ser analisados no contexto de um movimento europeu no qual "turistas românticos" e "exploradores solitários" da França oitocentista passaram a inserir interesse coletivo nos vestígios do passado, mediante a fundação do Estado nacional francês. ${ }^{7}$ Os registros desses cronistas, "já tocados pela noção de patrimônio", 8 são os primeiros inventários sobre o lugar e influenciaram a criação da ideia patrimonial.
4. O Templo Romano, datado do século I ou início do II, tornou-se monumento nacional ainda em 1907. Teria sido dedicado a Diana, a deusa dos caçadores, conforme historiadores antigos, ideia que foi refutada depois por pesquisas arqueológicas. Até 1870 , o rei D. Pedro V autorizou a requalificação do monumento, que era utilizado como açougue desde o século XIV, com a retirada das paredes de alvenaria e a consolidação das colunas originais pelo artista italiano José Cinatti (SILVA, 2011, p. 14). Ao caminhar pelas estreitas ruas do Centro Histórico de Évora é possível perceber que o apócrifo "Diana" perdura, dando nome a jardins, ruas, residenciais, restaurantes etc.

5. Cf. Choay (2011).

6. Rosas (2010, p. 41-46).

7. Leniaud (2002, p. 133).

8. Pesavento (2007, p. 58). 
9. Cf. Berliner; Istasse (2013).

10. Conforme conceito desenvolvido por Jadé (2009).
O reconhecimento de São Miguel como "lugar histórico" pelo governo do Rio Grande do Sul na década de 1920, seguido pelo tombamento nacional das ruínas de São Miguel, em 1938, foram fundamentais para elevar o passado jesúítico-guarani à narrativa predominante de identidade, o que se projeta no presente do município e da região. $\bigcirc$ passado das reduções jesuítico-guaranis se materializou nos remanescentes arquitetônicos e arqueológicos, agregando valores religiosos e artísticos, valores sociais de trabalho e de luta por igualdade, e tantos outros desdobramentos, conforme os usos do patrimônio em diferentes contextos e por diferentes atores. Aos bens materiais móveis e imóveis preservados soma-se a revisitação a fatos do passado reducional que consagrou nomes indígenas como heróis, e de jesuítas como mártires. $\bigcirc$ nome desses personagens irrompe no meio público dos municípios na região, como topônimos. $\bigcirc$ mesmo ocorre com o uso da imagem das ruínas de São Miguel em campanhas publicitárias e logomarcas comerciais.

Em Évora, o passado romano também agregou valores fundantes; todavia, por sua longevidade, a cidade passou por vários estágios de ocupação e uso do espaço urbano. Assim, diferente do que ocorre em São Miguel das Missões com os vestígios das reduções jesuítico-guarani, em Évora outros elementos, além dos vestígios romanos, passaram a ser valorados e a compor o repertório patrimonial. A milenar trajetória histórica da cidade legou um patrimônio diversificado, porém os vestígios da Évora romana conferem uma carga narrativa que assume grande importância em espaços públicos da cidade contemporânea, onde a imagem do Templo Romano também é utilizada em logomarcas de bancos, centros comerciais e restaurantes.

É possível delinear alguns paralelos entre as cidades, ambas inscritas na lista representativa de patrimônio da Unesco na década de 1980. Observa-se na correlação entre Évora e São Miguel a exacerbação de discursos em torno do passado, a espetacularização do patrimônio - em iniciativas de promoção turística e na iluminação e sonorização dos monumentos -, além das dificuldades para conciliar os interesses locais e a gestão do patrimônio nos parâmetros internacionais. Os usos comerciais e midiáticos, assim como a intervenção do poder público através de normatizações para preservação, acabam projetando os lugares para além dos sentidos locais que eles possuíam, configurando-os como "hiperlugares do patrimônio". 9

Para além de problematizar esses desafios, os quais perpassam os lugares que detêm o título de patrimônio mundial, busca-se aqui analisar alguns aspectos em torno do fazer patrimonial de cada localidade. A forma como o fato patrimonial ${ }^{10}$ foi instituído, os contextos históricos e de governança influíram nas políticas públicas 
e consequentemente imprimiram diferenças na maneira de organizar esse patrimônio, mesmo que na atualidade os dois sítios respondam a mecanismos de proteção e regulamentos comuns no escopo da lista do patrimônio mundial da Unesco. Para isso, optou-se por primeiramente retomar alguns eventos da composição patrimonial de cada localidade, passando em seguida à análise do enquadramento dos sítios na lista da Unesco nos anos 1980. Por fim, através de entrevistas com representantes dos poderes públicos locais à época da candidatura na Unesco e com os atuais profissionais responsáveis pela gestão, busca-se discutir aspectos desse manejo patrimonial e das relações estabelecidas com as comunidades.

\section{ÉVORA, HISTÓRIA E PATRIMÔNIO}

Capital da região do Alentejo e distante 135 quilômetros de Lisboa, Évora apresenta vestígios materiais de distintas épocas e influências culturais que compuseram o contexto urbano atual. $\bigcirc$ centro histórico milenar, delimitado pelas muralhas, foi inserido na lista do patrimônio mundial no ano de 1986.

No período das navegações, durante o final dos anos 1400 e início de 1500, a corte portuguesa estava estabelecida na cidade, e desde então houve uma valorização de acontecimentos da Antiguidade para enfatizar a importância da cidade muralhada. Nesse período o elemento romano foi destacado como vetor para a consagração da cidade, por intermédio do trabalho do historiador André de Resende (1500-1573), um intelectual dominicano nascido em Évora, que estudou e atuou em diversas universidades europeias, exercendo funções diplomáticas e prestando serviços à família real. ${ }^{11}$

Resende foi responsável por escrever uma vasta obra sobre a Antiguidade, exaltando a resistência lusitana. Ainda no século XVI, chegou a criar simulacros de materiais epigráficos da Antiguidade como forma de "atingir os objetivos políticosreligiosos e culturais a que se propusera". ${ }^{12}$ Tais elementos consistem em um conjunto de estelas e lápides que hoje se encontram no Museu de Évora e que enaltecem uma possível vitória dos lusitanos, comandados pelo general Sertório, contra os romanos. Os escritos serviam para, através do mito de Sertório, um "caudilho lusitano", 13 atestar a importância da cidade no império português. Também datam do período quinhentista algumas construções que reproduzem elementos arquitetônicos romanos, como a caixa d'agua da Rua Nova, hoje monumento protegido (Figura 1).
11. Sobre a vida de André de Resende, cf. Vasconcelos (1996).

12. D'Encarnação (2002, p. 305)

13. Id. (2009, p. 105). 
14. Cf. Cátedra (2009)

15. Ibid., p. 426 .
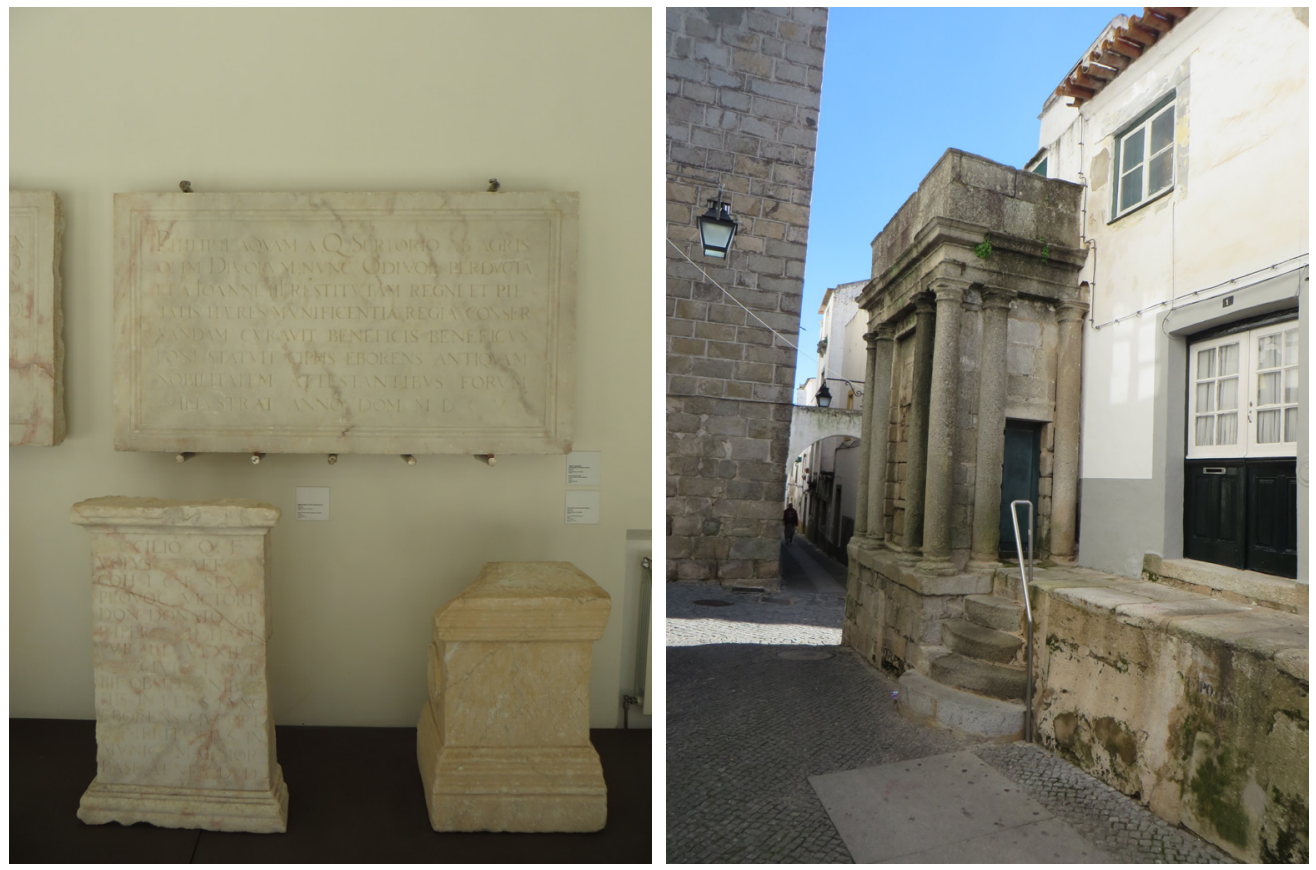

Figura 1 - Estelas e lápide produzidas por André de Resende (Coleção do Museu de Évora) e caixa d'água da Rua Nova. Fotografias: Darlan De Mamann Marchi, 2016.

Na constituição da identidade eborense, o período romano - quando a cidade era denominada Liberalitas Iulia e obteve seu apogeu, entre 25 a.C. a 14 d.C. - foi evocado desde muito cedo. André de Resende foi responsável pela "descoberta da antiguidade romana", delegando a Sertório o papel do herói que convertera a cidade em município livre, com o título de "Liberdade lulia", conjecturando sua ligação com o imperador Júlio César. ${ }^{14}$ Com a consagração de Évora, Resende visava a destacar também a importância central da cidade no território da antiga Lusitânia, ocupada desde os tempos romanos por figuras importantes e depois por reis portugueses como D. Alfonso Enriques e D. Sancho I. Por outro lado, a construção dessa narrativa destacando acontecimentos romanos e cristãos "obscureceu outros aportes étnicos", o que se constata na pouca informação sobre os 451 anos em que Évora esteve sob dominação muçulmana. ${ }^{15}$

No discurso da reconquista de Évora desponta a figura mítica do nobre herói "Giraldo, o Sem Pavor", que no século X foi responsável por retomar a cidade das mãos dos mouros. No coração da cidade muralhada, a praça principal recebeu o nome de Giraldo, sendo ainda hoje o centro cultural e comercial da cidade. Assim, a figura do mouro como inimigo, antítese dos valores cristãos, promoveu a invisibilidade da contribuição muçulmana na constituição de Évora. Tal processo já era visível à época de André de Resende e foi paulatinamente 
reforçado pela escolha de três períodos que definiram os paradigmas para a proteção do patrimônio: o romano, o cristão e o da Reconquista. ${ }^{16}$ Assim, na sobreposição de narrativas míticas que caracterizaram a cidade, o passado romano se constituiu como o primeiro articulador da identidade local, dividindo espaço posteriormente com os remanescentes de uma cidade forjada nas cortes cristãs.

A história do patrimônio em Évora possui outro elemento importante, destacado por pesquisadores e gestores que trabalham no campo do patrimônio: o envolvimento de uma intelectualidade ativa, atuante na defesa do patrimônio cultural desde o final do século XIX. ${ }^{17} \bigcirc$ Templo Romano, restaurado na segunda metade do século XIX e até então utilizado como açougue municipal, foi conduzido ao patamar de monumento pela campanha de personalidades políticas e intelectuais, que retomaram a tradição de valorizar e ressignificar o passado romano $^{18}$ (Figuras 2 e 3 ).

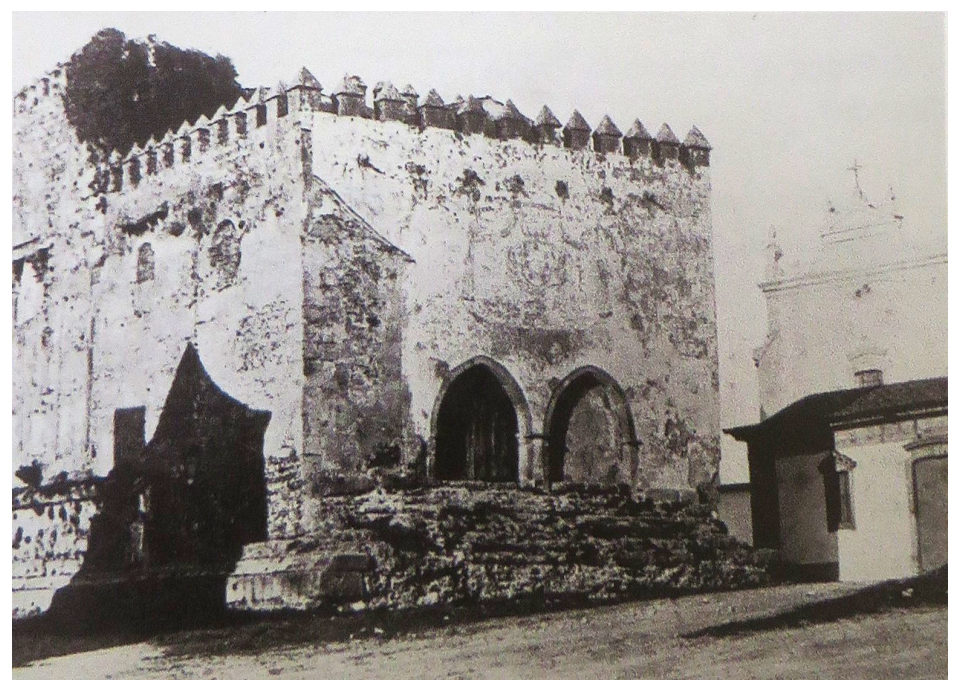

Figura 2 - Templo utilizado como açougue municipal. Reprodução fotográfica: António Franco, 1945. Fonte: Arquivo Histórico da Câmara Municipal de Évora.

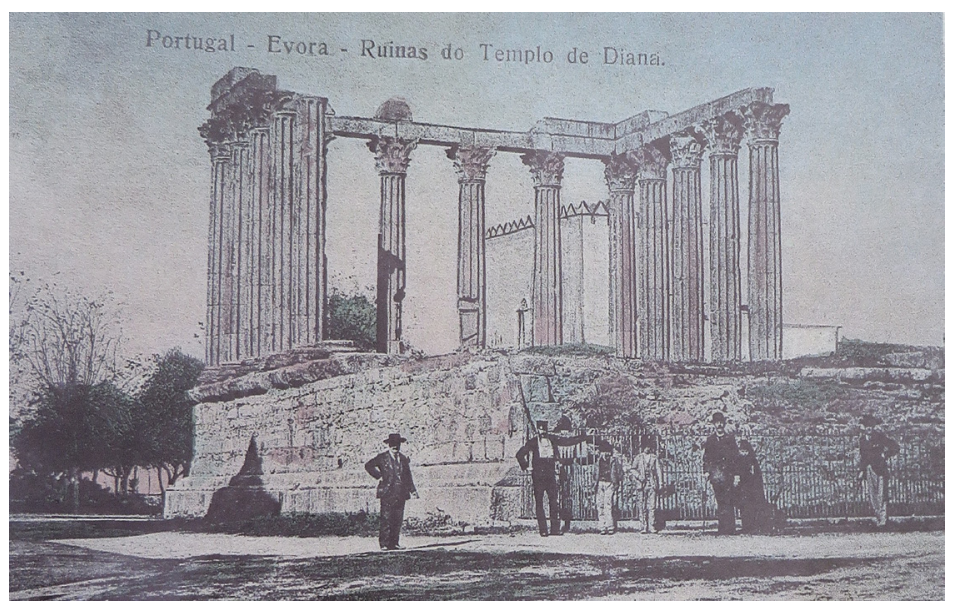

Figura 3 - Templo Romano após a restauração, final do século XIX. Reprodução de postal. Fonte: Arquivo Histórico da Câmara Municipal de Évora.
16. Períodos estabelecidos por Cátedra (2009).

17. Sobre a ação dos intelectuais na defesa do patrimônio em Évora, cf. Rodrigues; Matos (2007).

18. Sobre os usos do Templo Romano, cf. Cátedra (2011). 
19. Almeida et. al (2001, p. 64-68)

20. Informações disponibilizadas em entrevista por Celestino David (2016), diretor do Grupo Pró-Évora. Importa evidenciar que o entrevistado é neto de um dos fundadores do grupo, o que denota também o caráter geracional na composição do Pró-Évora.

21. Custódio (2010, p. 59)

22. Rodrigues (1999, p. 9-11).

23. Miranda (2016).

24. Almeida et al., op. cit., p. 127.
No princípio do século XX, com a afirmação do Regime Republicano, ocorrem as primeiras ações oficiais de reconhecimento de monumentos nacionais na cidade, datando dessa época a organização efetiva da sociedade civil através da intelectualidade local, que em 1919 criou o Grupo Pró-Évora, primeira associação organizada em Portugal para a defesa do patrimônio ${ }^{19}$ e que segue em funcionamento até os dias atuais. Os intelectuais que compuseram o grupo desde cedo atuaram tanto na reivindicação junto aos poderes públicos, como no patrocínio de atividades de restauração de bens culturais, bem como em campanhas de conscientização das populações sobre a importância dos monumentos. O Pró-Évora chegou a produzir o primeiro inventário dos bens culturais da região - ainda hoje uma referência nos estudos do patrimônio -, elaborado ao longo da vida de Túlio Espanca, um dos membros do grupo. ${ }^{20}$

No plano nacional, somente no final do século XIX e início do XX foram instituídos os primeiros serviços de patrimônio em Portugal. Em 1889, durante a Exposição Mundial em Paris, o país já possuía representação da Comissão Nacional de Museus no Primeiro Congresso Oficial Internacional para a proteção das Obras de Arte e Monumentos, evento no qual foi proposto aos países o incentivo às ações em defesa do patrimônio. ${ }^{21} \bigcirc$ Grupo Pró-Évora faz parte desse contexto, sendo uma das associações que obteve representação e influência sobre as entidades públicas portuguesas, contribuindo, ainda nos anos 1920, para a inclusão de diversas edificações de Évora na lista de classificação do patrimônio nacional. Nos anos que se seguiram, e mesmo durante o Estado Novo (1933-1974), o grupo também atuou no fortalecimento e na recuperação de acervos do Museu e da Biblioteca Pública de Évora, no movimento pela criação de estruturas de hospedagem, catálogos de turismo e formação de guias, promovendo diversas iniciativas de exposições de arte e de formação profissional, além da promoção nacional e internacional do patrimônio local. ${ }^{22}$

Durante o Estado Novo se desenrola outra fase das políticas patrimoniais na cidade. Conforme o arquiteto Eduardo Miranda, responsável pelo Departamento do Centro Histórico de Évora, ${ }^{23}$ entre as décadas de 1930 e 1960 ocorreram diversas intervenções de salvaguarda "de acordo com o que era a doutrina da época". A atividade de restauro de imóveis e monumentos nessa fase visava a suprimir qualquer elemento anexo mais recente, "limpando-o[s] de tudo o que não fosse genuíno". ${ }^{24}$ 
No ano de 1937 a Câmara Municipal aprova o Regulamento Geral de Construção Urbana para a Cidade de Évora, que visava à "manutenção da imagem urbana tradicional", momento em que também ocorre a alteração intencional de fachadas oitocentistas, caracterizando o "português suave" como a "arquitetura oficial" da cidade. ${ }^{25} \mathrm{Na}$ década de 1940, com o deslocamento de levas populacionais do campo para a cidade, há um crescimento desordenado do espaço urbano, principalmente da cidade extramuros. Assim, em 1945 o Anteprojeto Geral de Urbanização de Évora, realizado por Etienne de Gröer, acabaria por definir critérios e estratégias para a proteção de edifícios e fachadas, promovendo também o zoneamento da cidade. ${ }^{26}$ Essas ações contribuiriam tanto para a preservação de monumentos isolados (por exemplo, a Sé Catedral, o Colégio do Espírito Santo, o Palácio Real, entre outros), como para a manutenção de um significativo conjunto de arquitetura vernacular portuguesa, o que contribuiu para que Évora ficasse conhecida no contexto nacional como a "Cidade Museu".

Tal entendimento se encontra no Plano de Gestão do Centro Histórico de Évora, atualizado em 2013 , que estabelece ações e diretrizes para a gestão do patrimônio e discorre também sobre os motivos que levaram a cidade a desenvolver uma trajetória patrimonial e de preservação diferente de outras cidades portuguesas do mesmo período. ${ }^{27}$ Ao reconhecer a inexistência de uma resposta objetiva para tal questão, os especialistas responsáveis pelo Plano enumeram algumas possíveis causas: o período de estagnação da economia local; a extrema ligação das pessoas da região com as tradições de seus antepassados; dificuldades jurídicas e financeiras que não permitiram a modernização e renovação das estruturas urbanas; a atração provocada pelos vestígios materiais do passado em intelectuais e artistas, desde o Renascimento até o século XX; algumas ações de destruição e degradação de importantes edifícios que levaram à organização da sociedade civil, com particular destaque para o surgimento do Grupo Pró-Évora; e, por fim, as intervenções realizadas a partir dos anos 1930, como as restaurações de imóveis históricos promovidas pela Direção Geral de Edifícios e Monumentos Nacionais e a conclusão do Regulamento da Construção Urbana, que consolidam uma política de preservação. ${ }^{28}$

Todos os motivos levantados demonstram a convergência de vários elementos para que a cidade mantivesse seu patrimônio até os dias atuais. Nesse arrolamento de justificativas se pode observar a influência de contextos políticos e econômicos, bem como a ação e os desígnios convergentes entre sociedade civil, intelectualidade e poder público.
25. Miranda (2009, p. 25).

26. Ibid., p. 25-26.

27. Portugal (2013, p. 80).

28. Ibid., p. 81. 
29. Arquivo Histórico Municipal Augusto César Pereira dos Santos (1901-1927).

30. Lúcio Costa foi um importante arquiteto brasileiro e um dos principais colaboradores do Instituto do Patrimônio Histórico e Artístico Nacional (Iphan) e ficou mundialmente reconhecido pelo planejamento urbanístico de Brasília, ao lado de Oscar Niemeyer. Nessa visita técnica às Missões, uma das primeiras realizadas pelo arquiteto, a pedido de Rodrigo Mello Franco de Andrade, escritor e primeiro diretor do SPHAN, Costa cita em seu relatório a prática da venda de pedras pela municipalidade de Santo Ângelo. O arquiteto não esconde o encantamento por uma casa popular do fim do século XVIII construída com as pedras do antigo povoado, e sugere o tombamento do imóvel (Costa; Pessôa, 1998). A casa foi o primeiro bem de fato tombado no Rio Grande do Sul pelo SPHAN, tendo sido demolida tempos depois de maneira até hoje inexplicável (cf. Meira, 2008).

31. Sobre essas obras, cf. Stello (2005).

\section{SÃO MIGUEL: DO ABANDONO AO PATRIMÔNIO}

O sítio histórico e arqueológico de São Miguel Arcanjo, localizado na cidade de São Miguel das Missões, na região noroeste do estado do Rio Grande do Sul, é o único bem cultural no Sul do Brasil inscrito na lista do patrimônio mundial da Unesco. Ao contrário de Évora, São Miguel das Missões não se constitui em torno de um centro histórico urbano, uma vez que os objetos da patrimonialização foram os remanescentes arquitetônicos e arqueológicos da missão jesuítica ali instaurada nos séculos XVII e XVIII, em um espaço histórico e arqueológico que hoje possui 38 hectares.

Na segunda metade do século XIX, com o domínio do território pelo império brasileiro, novas urbes foram estabelecidas sobre os remanescentes materiais das reduções jesuítico-guarani. À diferença de outros povoados que foram se configurando como novas cidades (casos de Santo Ângelo, São Boria e São Luiz Gonzaga), São Miguel, devido a sua localização, foi ocupada tardiamente, o que manteve a relativa integridade dos vestígios arquitetônicos, principalmente da fachada e estrutura da igreja jesuítica.

No início do século XX as ruínas da antiga igreja foram assoladas pela retirada de pedras que seriam reutilizadas em outras construções. Entre 1901 e 1925 vigorava em Santo Ângelo (cidade da qual a Vila de São Miguel das Missões era distrito), no escopo da Lei Orçamentária do Município, ${ }^{29}$ uma taxa específica sobre o metro cúbico de pedras retiradas dos "Povos Jesuíticos de S. João e São Miguel". As pedras dos povoados missioneiros foram empregadas sobretudo para construção de novas residências, prática denunciada no relatório elaborado por Lúcio Costa, quando de sua visita técnica às ruínas em 1937.30

Porém, a abordagem sobre a história do patrimônio na região missioneira ocorre geralmente no quadro da formação das políticas nacionais de patrimônio e do Serviço do Patrimônio Histórico e Artístico Nacional (SPHAN), logo após a Revolução de 1930 e a instituição do Estado Novo, o que tem suplantado a importância da patrimonialização em nível local. Antes mesmo da ação federal, ainda nos anos 1920 o governo republicano-positivista do Rio Grande do Sul reconheceu São Miguel como "Lugar Histórico" na legislação da Comissão de Terras e Colonização, promovendo as primeiras obras de manutenção das ruínas da igreja entre 1925-192731 (Figura 4). 


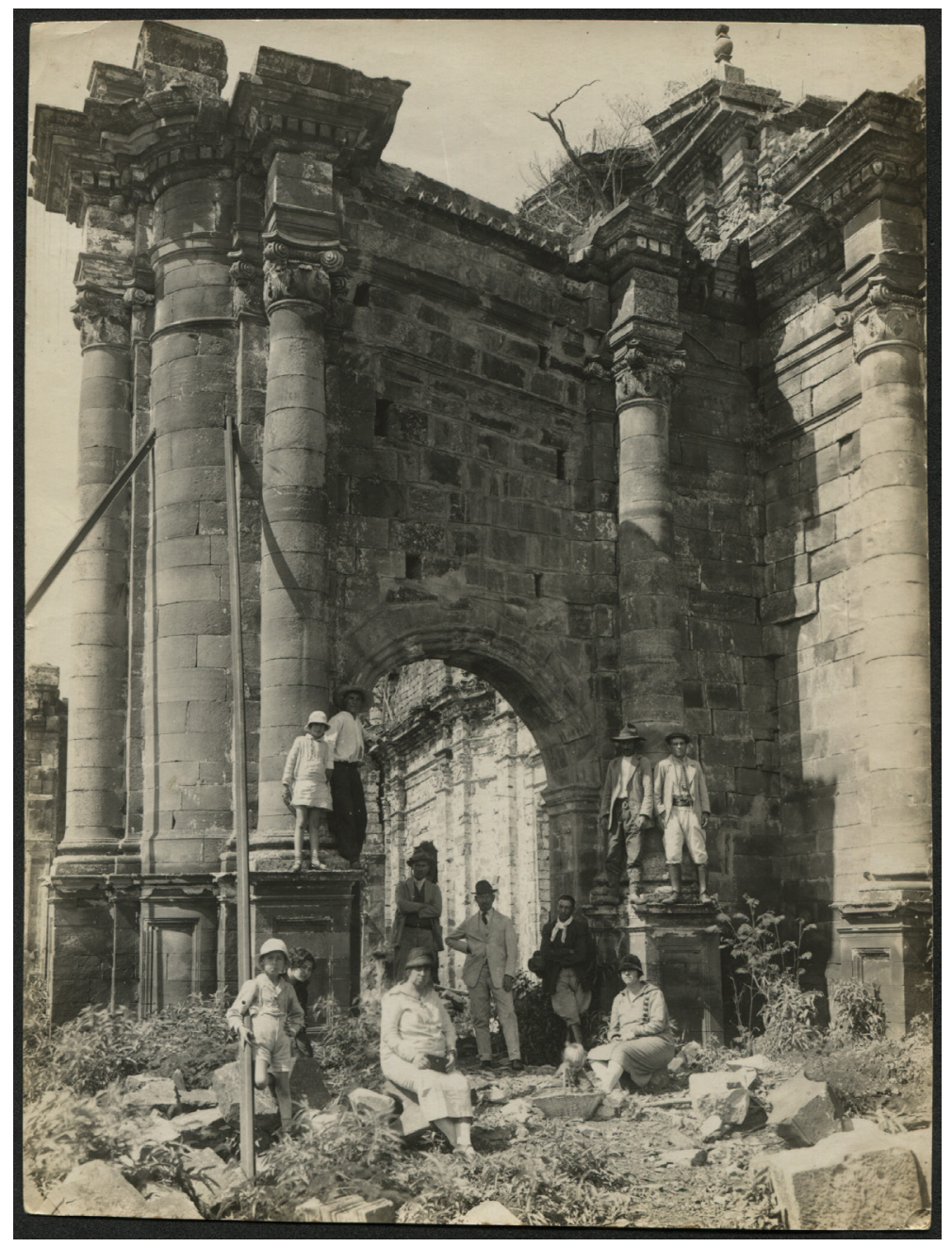

32. Sobre o conceito de ativação patrimonial, cf. Prats (1998).

Figura 4 - Fotografia do período das obras, década de 1920. Série Inventário. Fonte: Arquivo Central do Instituto do Patrimônio Histórico e Artístico Nacional.

No século posterior à expulsão dos jesuítas do território (1768-1769), um complexo quadro de disputas pelo território dos Sete Povos missioneiros do lado oriental do Rio Uruguai continuou até a definitiva ocupação pelo império brasileiro em 1828. Toda essa instabilidade provocou uma crise demográfica e ocupações irregulares nas áreas das antigas reduções. $\bigcirc$ contexto social foi sendo alterado de maneira significativa entre o final do século XIX e início do XX, quando se dá o processo de repovoamento da localidade. A ativação do patrimônio ${ }^{32}$ ocorreria por uma série de fatores que remetiam à possível perda desses elementos, os quais passavam a ser ressignificados por valores políticos e religiosos. 
33. Assembleia Legislativa do Rio Grande do Sul (1926. p. 448).

34. Cf. Gonçalves (1996).

35. Museu de Literatura Brasileira [193-].

36. Fonseca (2005, p. 101). 37. Chuva (2009, p. 48).
As obras de limpeza e estabilização das estruturas das ruínas, realizadas pelo governo do Rio Grande do Sul entre 1925 e 1927, foram justificadas no relatório da Secretaria de Obras Públicas pela necessidade de "retardar a destruição", já que as ruínas passavam a representar um "documento arquitetônico e religioso, sobretudo, dos esforços dos nossos maiores, especialmente dos jesuítas, no amparo e proteção dos silvícolas". ${ }^{33}$ As ações patrimoniais foram, nesse contexto, uma intervenção do poder público visando a salvaguarda de elementos materiais do passado colonial que estavam sob risco. Para além da retórica da perda, ${ }^{34}$ a motivação simbólica estava também na representatividade religiosa e "civilizadora" do trabalho dos jesuítas. Portanto, ainda não eram os critérios artísticos e estéticos que ditavam as ações de preservação e os valores relacionados ao patrimônio.

Outro momento do patrimônio em São Miguel ocorreu em 1938, quando as ruínas foram reconhecidas como patrimônio nacional. Nomeado primeiro representante do SPHAN no Rio Grande do Sul, o escritor modernista Augusto Meyer foi responsável pelo inventário indicativo de edifícios e obras a serem reconhecidas como patrimônio nacional. Nas primeiras correspondências enviadas por Rodrigo Melo Franco de Andrade a Augusto Meyer, as ruínas de São Miguel despontavam como elemento a ser preservado, recebendo atenção especial por parte do SPHAN. ${ }^{35} \mathrm{O}$ zelo atribuído às missões nesse período de constituição do patrimônio, tornando São Miguel o principal foco das políticas patrimoniais no Sul do Brasil, fica evidente, por exemplo, quando da visita técnica do arquiteto Lúcio Costa e dos investimentos federais destinados às ações indicadas pelo arquiteto para preservar aquele patrimônio: obras profundas de restauração e consolidação das ruínas, escavações arqueológicas e construção de um museu para exposição da estatuária barroco-missioneira recolhida na região. $\bigcirc$ museu, projetado pelo próprio Lúcio Costa, foi inaugurado em 1940 e se tornou uma das primeiras experiências de museus regionais construídos pelo instituto ${ }^{36}$ (Figura 5).

No quadro simbólico do período, as missões jesuítico-guarani - enquanto legado dos jesuítas, ao lado da arte e arquitetura das cidades coloniais mineiras - consagravam-se como representações de uma "ancestralidade para a nação, mantendo-se um elo de continuidade entre o Estado colonial e um novo Brasil independente" ${ }^{37}$ Somava-se a isso o fato de que o então novo mandatário da nação, líder do Estado Novo, era Getúlio Vargas, político republicano nascido em São Borja, na região missioneira. Rodrigo Melo de Franco Andrade, diretor do SPHAN, em função da necessidade de liberação orçamentária para as obras de restauração nas ruínas de São Miguel das Missões, destacava, em missiva direcionada ao ministro Gustavo Capanema: 
de resto, ninguém melhor do que o próprio Senhor Presidente da República, natural da região missioneira, ajuizará do valor dos vestígios da arquitetura jesúitica subsistentes no Rio Grande, dos quais os de S. Miguel são os únicos que conservam alguma coisa do aspecto da imponente construção primitiva. ${ }^{38}$

A relação do lugar patrimonializado com a figura de Getúlio Vargas vai aparecer em alguns momentos. $\bigcirc$ artigo de Alberto Lamego para a Revista do SPHAN, em 1940, ressaltava que: "no extremo noroeste do Estado do Rio Grande do Sul, à margem esquerda do Rio Uruguai, está situada a cidade de São Francisco de Borja, onde viu a luz do sol o Sr. Getúlio Vargas e que foi um dos Sete Povos das Missões". ${ }^{39}$ Outro exemplo está no livro Rio Grande do Sul: a terra e o homem, do alemão Wolfgang Hoffmann Harnisch, no qual o autor relata, de maneira propagandística ao regime, sua viagem pelo estado natal do "grande mandatário da nação" em 1941. No capítulo em que trata da região missioneira, Harnisch combina história local e relatos sobre o patrimônio preservado, destacando o lugar como "berço do Estado Novo". ${ }^{40}$ Assim, no espectro político o passado missioneiro também foi mobilizado ao longo do século XX, como um dispositivo para apregoar distintos valores políticos e sociais nas esferas nacional e regional.

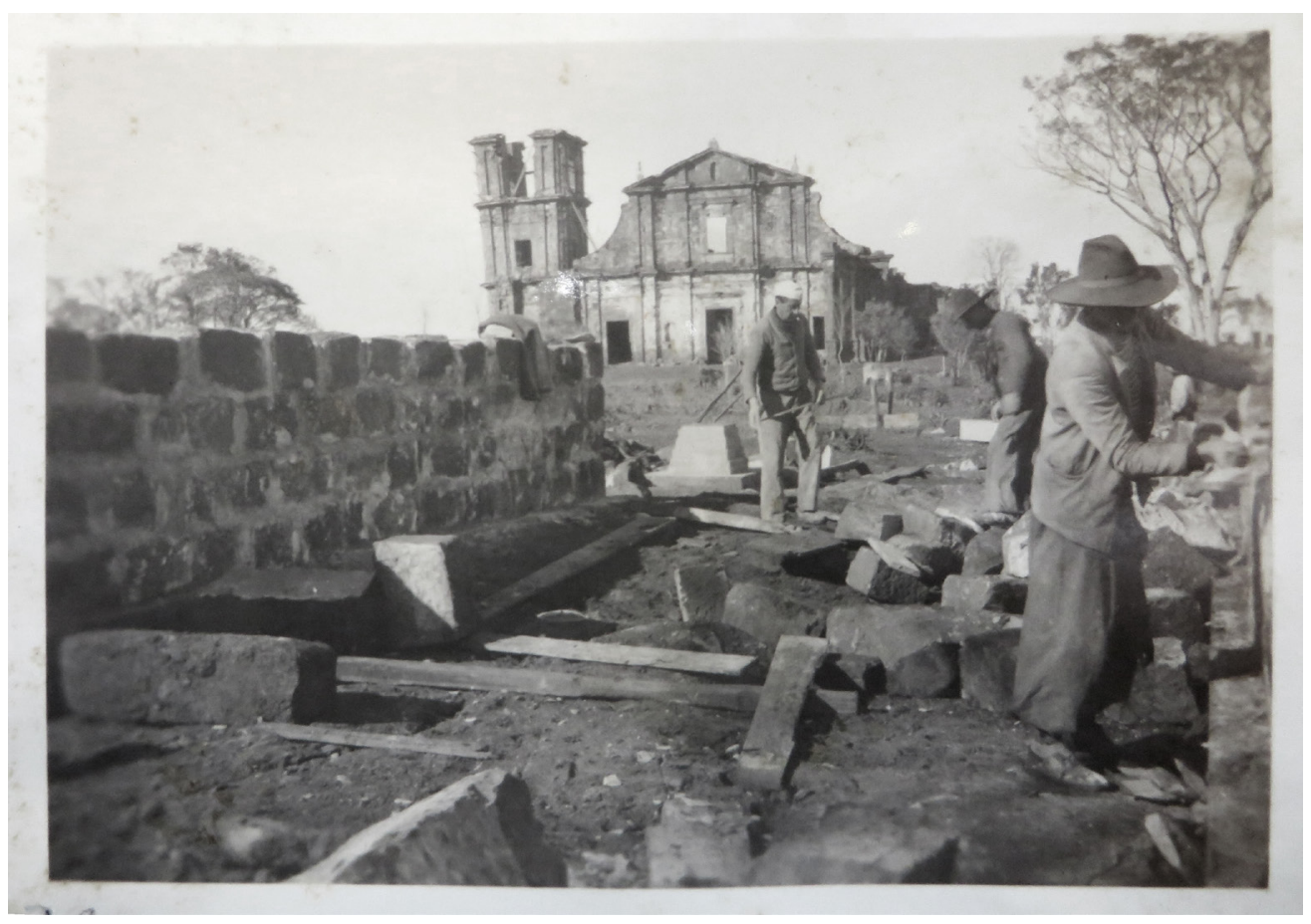

Figura 5 - Construção do Museu das Missões, final dos anos 1930. Fonte: Arquivo Central do Instituto do Patrimônio Histórico e Artístico Nacional.
38. Fundação Casa Rui Barbosa. Museu de Literatura Brasileira. Fundo Augusto Meyer (1937).

39. Lamego (1940, p. 56).

40. Harnisch (1952, p. 253). 
41. Cf. Hafstein (2007).

42. Cf. Marcotte; Bourdeau (2010).

43. Espetáculo Som e Luz (2015).

44. Cf. Marchi; Ferreira (2016).

45. Wbatuba (2017, p. 106).

\section{PATRIMÔNIO MUNDIAL EM QUESTÃO}

A instituição das listas do patrimônio tangível e intangível revela práticas seletivas, celebrando virtudes de determinado patrimônio, colocando em evidência um local específico. Entretanto, uma vez estabelecidas, essas listas classificatórias podem promover conflitos. No caso da lista do patrimônio mundial, esse aspecto pode ser observado no campo do turismo e na precedência que ele assume perante a preservação, ${ }^{41}$ ainda que a promoção turística não fosse relevante quando da inclusão das cidades na referida lista.

A atividade turística passa a ser resultado do caráter de excepcionalidade que o bem cultural adquire ao ser inserido numa lista representativa. A atribuição de "valor universal excepcional" aos lugares do patrimônio mundial provoca transformações que repercutem nas dinâmicas sociais e na forma como os sujeitos se relacionarão com seu "lugar-patrimônio". Ainda que não tenha sido o objetivo original da patrimonialização, o selo de patrimônio mundial tornou-se promotor de ações turísticas - muitas estimuladas pela Unesco, como programas e empreendimentos visando à parceria entre organizações turísticas e patrimoniais. ${ }^{42}$ Isso se torna bastante relevante no caso de Évora quando se observa que o turismo se converteu em um dos principais motivos de ingresso na cidade.

Em São Miguel das Missões, ainda em 1978 foi criado, por iniciativa do governo do Rio Grande do Sul, o espetáculo de Som e Luz. ${ }^{43}$ Com narrativa poética e histórica na voz de grandes atores brasileiros, através de luzes refletidas sobre as ruínas do Parque Histórico é contada a saga dos Sete Povos das Missões, constituindo um discurso mítico e libertário sobre a instauração e o declínio das reduções. $\bigcirc$ espetáculo se repete desde então, todas as noites, no espaço patrimonializado, sendo mantido atualmente pela prefeitura municipal. Todo seu equipamento foi modernizado entre 2015 e 2016, com investimentos do Banco Nacional do Desenvolvimento Econômico e Social (BNDES) (Figura 6). O espetáculo, pela longa duração, além da função turística, cumpre o papel de dispositivo patrimonial e identitário para a região. ${ }^{44}$ Todavia, o turismo ainda é uma área pouco representativa nas estatísticas econômicas da região, cuja força produtiva está basicamente na agropecuária. Conforme - Plano Estratégico de Desenvolvimento (2015-2030) da região das Missões, elaborado pelo Conselho Regional de Desenvolvimento (Corede-Missões), apesar de todo o potencial, ainda é preciso "profissionalizar a vocação turística" da região, uma vez que São Miguel recebe uma média de 80 mil turistas ao ano, mas tem capacidade para 200 mil. ${ }^{45}$ 


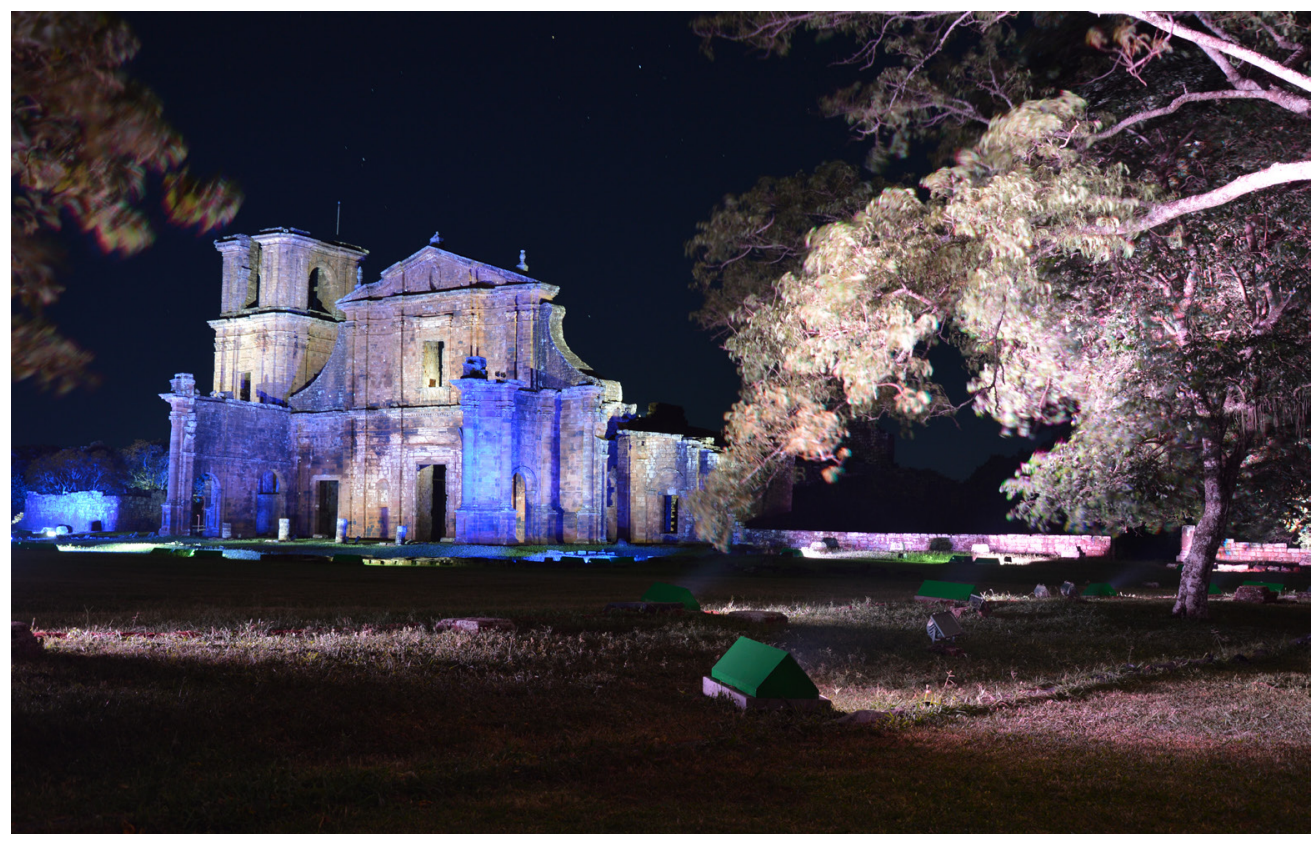

Figura 6 - Som e Luz de São Miguel das Missões. Prefeitura Municipal de São Miguel das Missões. Fotografia: Marconi Flach, 2016.

Tendência em outros monumentos e sítios patrimoniais em Portugal, também já ocorreram em Évora edições de espetáculos de video mapping, com projeções de imagens e sons sobre histórias e lendas locais (Figura 7). $\bigcirc$ artifício da iluminação dos monumentos soma-se a inúmeras atividades artísticas e culturais que têm como palco o Centro Histórico de Évora, podendo ser subvencionadas pela municipalidade ou por fundações como a Eugénio de Almeida, que investe na recuperação de imóveis históricos ${ }^{46}$ e em atividades culturais. Somente no ano de 2016, os estabelecimentos hoteleiros de Évora registraram um número de 334.472 hóspedes, mais do que o total de hóspedes em todos os municípios das cidades litorâneas do Alentejo, que foi de 282.708. ${ }^{47}$ Mesmo não sendo a principal área da economia na região do Alentejo, ficando atrás dos setores de agricultura, indústria, comércio e serviços, em 2016 o turismo foi responsável pela geração de 16 mil empregos formais em alojamentos e restaurantes. ${ }^{48}$

Entre Évora e São Miguel existem diferenças quanto aos processos de enquadramento patrimonial. Isso se deve ao contexto em que se inserem tais patrimônios, às referências temporais que os definem, bem como às inserções dos bens culturais em cada espaço social. Entretanto, o projeto de uma política global para o patrimônio através da Unesco permitiu incluir esses e outras centenas de lugares em uma estrutura de gestão e proteção, por meio da lista do patrimônio mundial, definida na Convenção de 1972.
46. Em 2013 a Fundação Eugénio de Almeida restaurou o Palácio da Inquisição, centro da Inquisição em Portugal no século XVI e XVII, e criou um Centro Cultural, denominado de Fórum Eugénio de Almeida. O edifício localiza-se no entorno do Templo Romano.

47. Instituto Nacional de Estatística (2017, p. 393394).

48. Ibid., p. 244. 
49. Harrison (2013, p. 64)

50. Peixoto (2002, p. 41).

51. Scifoni (2003, p. 84).

52. Cf. Peixoto, op. cit.

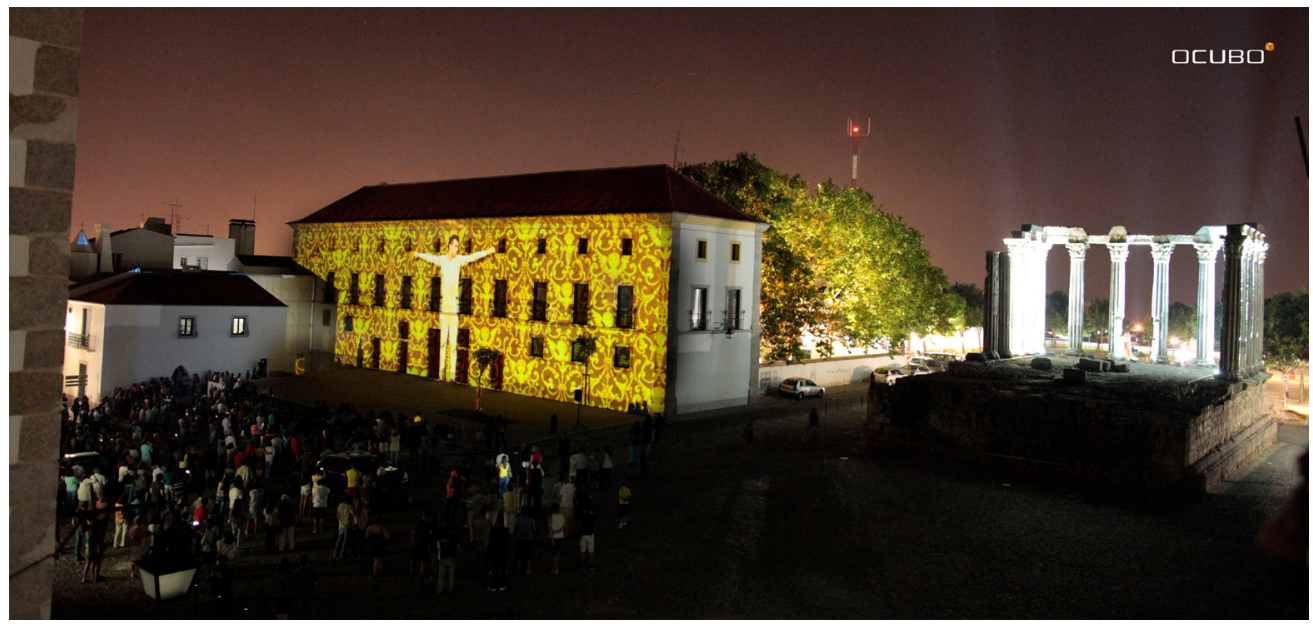

Figura 7 - Espetáculo de video mapping A Midsummer Night's Light. Fórum Eugênio de Almeida e Templo Romano. Fotografia: Ocubo Criativo, 2013.

Nos primeiros anos de aplicação da Convenção do Patrimônio Mundial, entre o final da década de 1970 e início dos anos 1980, foram inseridos na lista muitos bens culturais amplamente reconhecidos em seus países e que já haviam servido como representações para a constituição dos respectivos Estados nacionais. ${ }^{49}$ A partir de 1990 e no decorrer da primeira década do século XXI aumentam significativamente as candidaturas para compor a lista de patrimônio mundial, o que Paulo Peixoto denominou como "febre de patrimonialização", ${ }^{50}$ ou seja, um momento de corrida pelo status de patrimônio mundial. Muito rapidamente incorporado à indústria do turismo como um selo de autenticidade, originalidade e distinção, esse status passou a ser reivindicado pelos países membros da Unesco, signatários da convenção.

Os últimos anos da década de 1980 foram marcados pelo significativo aumento do número de países signatários da Convenção do Patrimônio Mundial. Se na década anterior o protagonismo havia ficado com os Estados Unidos e a proeminência do patrimônio natural, nessa cresce a representação de países asiáticos e sul-americanos, a exemplo da Índia e do México. ${ }^{51} \bigcirc$ ingresso desses países no cenário do patrimônio mundial significará, tal como ficará demonstrado mais tarde com o advento da lista representativa do patrimônio imaterial, uma sutil subversão da tendência eurocêntrica nesse tema, apontando para um cenário que na década seguinte seria identificado por uma curva em exponencial ascensão do número de cidades integrantes da referida lista. ${ }^{52}$

As ações patrimoniais em nível global fazem parte, e são também resultado, da "virada cultural" em que a linguagem passa a ter protagonismo na definição 
das "verdades", colocando-se como agente de classificação dos objetos e de criação de realidades. ${ }^{53}$ Nesse pressuposto, os elementos culturais de diferentes países, muitos dos quais já haviam dado suporte a determinados cenários nacionalistas, foram reenquadrados discursivamente a partir de um escopo global com a instituição da lista do patrimônio mundial. Configurava-se assim, também no âmbito de um organismo internacional, o rearranjo que ocorria no contexto geopolítico.

Observa-se no decorrer dos anos 1980 o fortalecimento de discursos que corroboram valores de uma sociedade globalizada e interconectada, nos quais eram enquadrados patrimônios referentes a momentos históricos que permitiam tal interpretação. Esses recortes do passado eram mobilizados como representativos de valores relativos à diversidade e ao multiculturalismo, temas fundantes das ações multilaterais da Unesco. Nesse sentido, observa-se o reconhecimento da influência islâmica na arte, história e arquitetura na península ibérica, e das civilizações da Antiguidade na área do mediterrâneo e da África. ${ }^{54}$ Nessa mesma linha, destacamse os bens inscritos na lista referentes ao período das grandes navegações e das relações entre metrópoles e colônias na América, dentre os quais se enquadra São Miguel das Missões.

Inserida nesse bloco no ano de 1983, a candidatura das ruínas do povoado jesuítico-guarani de São Miguel das Missões é aceita pela Unesco. Também em 1983, Portugal logra incluir quatro bens culturais na lista: o Centro Histórico de Angra do Heroísmo, o Mosteiro dos Jerônimos e Torre de Belém, o Mosteiro da Batalha e o Convento de Cristo em Tomar, sendo as duas primeiras candidaturas expressamente relacionadas às conquistas ultramarinas. Nos documentos do International Council of Monuments and Sites (lcomos) referentes à avaliação das candidaturas, tanto das ruínas de São Miguel como das candidaturas portuguesas, são destacados os valores relativos ao encontro de culturas e das influências positivas do Velho sobre o Novo Mundo, sobretudo nas artes, no avanço das ciências e no desenvolvimento de centros urbanos. ${ }^{55}$

Nos anos seguintes ainda seriam incorporados nesse escopo Cartagena de las Indias na Colômbia, em 1984; o Centro Histórico de Salvador e o Santuário de Bom Jesus em Congonhas, em 1985, ambos no Brasil; Igrejas e Conventos de Goa, em 1986; os Centros Históricos de Oaxaca, de Puebla e do Novo México, todos bens mexicanos inscritos em 1987; o Centro Histórico de Lima, no Peru, e a Cidade Velha de Galle e suas Fortificações, no Sri Lanka, em 1988. A Espanha é - exemplo maior desse período, com quinze bens culturais inscritos na lista entre 1984 e 1988, tendo despontado nos anos 2000 como o país com mais bens culturais inscritos na lista do patrimônio mundial. ${ }^{56}$ Diversas candidaturas espanholas
53. Cf. Hall (1997).

54. Destaca-se a inclusão na lista de sítios como: Palmira, no ano de 1980; Medina de Fez, em 1981; Sítio Arqueológico de Cirene, 1982; Alhambra e Granada, 1984; Byblos, 1984; Centro Histórico de Córdoba, 1984; Tyr, em 1984; Cidade Velha e Aqueduto de Segóvia, 1985; Petra,1985; Arquitetura mudejár de Aragón, 1986; Centro Histórico de Toledo, 1986; Nemrut Dag, 1987; Sitío Arqueológico de Delfos, 1987; Cidade Velha de Salamanca, 1988; Cidade medieval de Rhodes, 1988.

55. Organização das Nações Unidas para a Educação, a Ciência e a Cultura (1986).

56. Cf. Peixoto, op. cit., p. 28. 
57. Organização das Nações Unidas para a Educação, a Ciência e a Cultura (1983).

58. Id. (1984).

59. Id. (2005).

60. Cf. Williams (2012).

61. Os critérios se referem a: "(ii) ser testemunho de um intercâmbio de influências considerável, durante um dado período ou numa determinada área cultural, sobre o desenvolvimento da arquitetura ou da tecnologia, das artes monumentais, do planeamento urbano ou da criação de paisagens; [...] (iv) representar um exemplo excecional de um tipo de construção ou de conjunto arquitetônico ou tecnológico, ou de paisagem que ilustre um ou mais períodos significativos da história humana" (Organização das Nações Unidas para a Educação, a Ciência e a Cultura, 2011, p. 16-17).

62. Organização das Nações Unidas para a Educação, a Ciência e a Cultura (1986, tradução do autor).

63. Ibid. eram representativas da multiculturalidade, como a inserção na lista em 1987 da Catedral, Alcazár e o Arquivo das Índias em Sevilla, que conjugava na mesma candidatura as referências do período de dominação islâmica e da conquista da América.

Outro elemento característico dessa profícua década de 1980 foi a trasnacionalidade dos elementos culturais e o trabalho conjunto entre países. Em 1983 as "ruínas monumentais do Povo de São Miguel das Missões" foram inscritas na lista da Unesco; no ano seguinte, foram reunidos na mesma candidatura outros quatro sítios jesuítico-guaranis em território argentino. ${ }^{57}$ Conforme observações realizadas pelo Comitê ainda em 1983 e reafirmadas em 1984, os elementos relativos às missões jesuíticas dos Guarani deveriam ser reunidos, buscando também a inserção de bens culturais em território paraguaio e uruguaio, porém os dois Estados ainda não haviam aderido à Convenção do Patrimônio Mundial. ${ }^{58}$

Na apresentação atualizada dos bens culturais, que se encontra na World Heritage List, ${ }^{59}$ a característica transnacional dos sítios patrimonializados é destacada, apesar de os relatos do tratamento do patrimônio estarem em separado no texto, conforme as políticas aplicadas em cada país. Ainda em finais dos anos 1960 foram ensaiadas aproximações entre Argentina, Paraguai e Brasil para o desenvolvimento de ações conjuntas em torno do patrimônio e do turismo, as quais avançaram, entretanto, somente entre o Brasil e a Argentina, com a elaboração da candidatura de São Miguel das Missões. Esses acordos transnacionais eram vistos com bons olhos pela Unesco, que prestigiou nos anos 1980 a iniciativa conjunta dos dois países, possibilitando que a unificação das candidaturas das missões jesuíticas dos Guarani se tornasse o primeiro bem cultural transnacional da lista. .0

Os critérios II e IV da Convenção de $1972^{61}$ foram acatados para o reconhecimento de Évora como patrimônio mundial, devido a sua referência para o desenvolvimento da arquitetura portuguesa em cidades brasileiras e por ser o melhor exemplo de uma cidade "da idade do ouro de Portugal". 62 O critério II da Convenção é apontado pelo Icomos para qualificar o bem cultural sob o seguinte argumento: "a paisagem urbana do Centro Histórico de Évora é um lugar único para entender as influências exercidas pela arquitetura portuguesa no Brasil, em locais como o Centro Histórico de Salvador de Bahia". ${ }^{63}$ Assim, a valorização do centro histórico da cidade europeia como modelo para a urbanização na colônia ultramarina conectava "os dois mundos", ressaltando a influência sobre a cidade de Salvador, Bahia, cujo Centro Histórico foi inscrito na lista de patrimônio mundial um ano antes, em 1985. 
Na perspectiva da multiculturalidade, ambas, Évora e São Miguel, 64. Cf. Cunha (1994). apresentam características singulares que fundamentaram os processos de patrimonialização. No caso de Évora, os diversos registros e contatos culturais atestam as diferentes temporalidades que a identificam. Evidências pré-históricas, território de ocupação celta, zona de domínio romano, visigótico e árabe, acrescidos de testemunhos renascentistas e barrocos estão presentes na cidade, compondo um cenário no qual tempo e espaço se imbricam indissociavelmente. Em São Miguel os valores estão relacionados ao encontro de culturas e ao imaginário construído sobre uma experiência mítica de uma sociedade utópica entre indígenas e europeus, à qual se soma ainda o componente transnacional, mencionado anteriormente.

No que tange ao contexto interno, o período das grandes navegações e a dominação colonial dos territórios de ultramar representam um marco fundamental para a identidade nacional portuguesa, fomentado por investimentos em publicações, pesquisas e eventos nacionais ainda durante o regime salazarista. ${ }^{64}$ Não por acaso, os referenciais materiais da expansão colonialista portuguesa são os primeiros elementos das candidaturas ao patrimônio mundial nos anos 1980; no caso de Évora, mesmo sendo uma cidade referência para a formação da territorialidade da metrópole portuguesa, também se ressalta sua relação com o ultramar.

Nessa mesma linha o governo brasileiro, ainda no Estado Novo, através do SPHAN, encontrou na arquitetura e em obras do passado colonial o terreno sobre o qual se fundamentariam os discursos identitários nacionalistas na primeira metade do século XX. Tornaram-se então ícones do nacionalismo brasileiro lugares como Ouro Preto, São Miguel das Missões, o Centro Histórico de Salvador, o barroco de Aleijadinho em Congonhas, os quais, com suas candidaturas ao patrimônio mundial, inseriam-se nesse discurso cultural ampliado. Os traços de um passado comum, com referenciais nem sempre compartilhados e muitas vezes até divergentes, sob a égide da Unesco, tornaram-se elementos para coadunar políticas internacionais de convergência entre países, mas não deixaram de reforçar internamente os respectivos discursos e as referências de cada nacionalidade.

$\bigcirc$ paradigma de sociedade pós-colonial, no qual adentram discursos de compartilhamento de referências, de integração dos elementos comuns entre os países - o discurso da transnacionalidade - levou à criação de redes, acordos e outras iniciativas entre países no que se refere ao patrimônio. Exemplo recente disso, nos anos de 2006 e 2010, foi a realização pela Universidade de Coimbra de encontros com representações de diversos países que detêm sob suas jurisdições bens culturais de origem ou influência portuguesa na lista da Unesco. 
65. Comissão Nacional da Unesco (2014, p. 44).

66. Ibid., p. 48-49.

67. Organização das Nações Unidas para a Educação, a Ciência e a Cultura (2013, p. 168-169).

68. Harrison (2013, p. 89).

69. Yan (2015).

70. Haiming Yan (op. cit., p. 65-66) analisa nesse artigo o episódio ocorrido no dia 9 de agosto de 2008, na aldeia de Tulou, um mês após a designação do local como patrimônio da humanidade. Naquele dia os moradores locais protestaram em frente à plataforma de turismo; um dos habitantes atirou contra representantes do poder público enquanto gritava: "Aumente a participação na receita do ingresso! Caso contrário, vamos queimar a plataforma".
World Heritage Portuguese Origin (WHPO) tornou-se oficialmente uma rede no encontro de 2010, através da Declaração de Coimbra assinada pelos 26 países participantes. A declaração em tom poético, uma vez que inicia com o "Poema mestiço" de Mia Couto, reafirma a intenção de "iniciar um projeto de futuro, fundado no que hoje nos une e que também já nos separou: a história". 65 Essa rede, na qual foram associados dez patrimônios mundiais brasileiros de influência portuguesa, também inclui as Ruínas de São Miguel das Missões. ${ }^{66}$ Além da declaração e de uma carta de intenções, ao que parece a rede não obteve maiores avanços do ponto de vista legal e estatutário, não ocorrendo outros encontros depois de 2010. Entretanto, a iniciativa da Rede do WHPO aparece em 2013 no conteúdo da candidatura da Universidade de Coimbra para a lista do patrimônio mundial. A Universidade, que ao longo de sete séculos tem sido "a Universidade da língua Portuguesa no Mundo", com a promoção de ações ałuais como a da Rede WHPO buscava demonstrar que culturalmente ainda possui influência no mundo lusófono, desenvolvendo "o seu percurso de Universidade para o novo mundo". 67

Assim, sem maiores impactos ou resultados objetivos no sentido de desenvolver cooperações técnicas e sistemas de apoio mútuo, algumas iniciativas de trabalho em rede, como o caso da Rede WHPO, parecem somente cumprir critérios protocolares, que visam a interesses específicos. Os valores universais sobre referências culturais compartilhadas, reciprocidade, construção coletiva de soluções, somados a questões diplomáticas, são dissipados quando se transformam em estratégias burocráticas para alcançar êxito nas candidaturas propostas à Unesco. Esse é um exemplo do paradoxo que paira sobre o patrimônio mundial, pois, de um lado, procura-se evidenciar valores de diversidade e solidariedade entre países e culturas, e de outro, o exponencial crescimento de candidaturas e de países aderentes à Convenção tem promovido uma competição em função dos dividendos econômicos agregados pelos roteiros turísticos internacionais. ${ }^{68}$

Nessa perspectiva se multiplicam os exemplos de lugares onde o patrimônio mundial se converte em risco, mais ou menos controlável, para a manutenção de modos de vida tradicionais. Exemplo disso é o estudo feito por Haiming Yan ao analisar o caso de Fujian Tulou, na China, localidade inscrita na lista do patrimônio mundial desde 2008. Nessa pesquisa Haiming Yan demonstra como os modos de vida tradicionais e as relações sociais da população local foram alterados em função de interesses das elites e do governo local, o que gerou manifestaçães de rechaço por parte da comunidade local perante as políticas patrimoniais. ${ }^{69} \bigcirc$ pesquisador demonstra como o título, que apregoava o lugar como um modelo de harmonia, paradoxalmente desorganizou as formas tradicionais de agricultura e de intervenção nos edifícios históricos. ${ }^{70}$ 
A categoria de patrimônio mundial traz em si as fragilidades do patrimônio como um todo uma vez que, ao iluminar determinada face, obscurece outra; ou seja, a inscrição nessa lista pode afirmar determinadas narrativas históricas e minimizar ou mesmo excluir outras. ${ }^{71}$ No caso de Évora, é perceptível que a herança romana, como o templo atribuído popularmente à Diana, passa a ter um caráter centralizador, tornando-se marca visual da cidade. Já os vestígios medievais, por exemplo, apresentam-se menos demarcados e explorados como elementos de um passado a ser exposto. $\bigcirc$ mesmo quadro, resguardando-se as peculiaridades, pode ser observado no cenário de São Miguel, onde o discurso patrimonial aponta a herança missioneira como a que articula o passado histórico, subtraindo, portanto, temporalidades mais recentes que compõem igualmente o cenário local. Pode-se citar, por exemplo, a variedade arquitetônica e de manifestações culturais das colônias rurais provenientes da imigração europeia lalemães, italianos, russos, poloneses) que compõem a paisagem regional, ${ }^{72}$ mas que não recebem o mesmo destaque dos bens culturais do período jesuítico-guarani.

A construção de discursos fundadores, legitimados pela empresa patrimonial, imprime novas relações com o espaço, elemento de conexão entre o sujeito e outras temporalidades. Essa reapropriação do lugar, ativada agora pelo valor atribuído pela patrimonialização, tende a estabilizar e reafirmar alguns passados em detrimento de outros.

\section{GESTÃO DO PATRIMÔNIO MUNDIAL E APROPRIAÇÕES LOCAIS}

Mesmo que discursivamente a declaração de patrimônio mundial reafirme a soberania e as responsabilidades dos Estados nacionais para com o bem patrimonial, o processo de gestão revela tensões e contradições. ${ }^{73}$ Colocando-se como mediadoras entre as instâncias locais e o plano internacional, as representações da Unesco agenciam poder e autoridade que, embora sejam considerados positivos, aparecem tensionados por necessidades e clamores por vezes surdos aos ouvidos patrimoniais.

A entrada de Portugal na Unesco ocorreu em 1980, poucos anos após a ditadura salazarista, quando a sociedade portuguesa havia passado por uma duradoura guerra colonial e, após a Revolução de abril de 1974, vivia um processo de redemocratização das suas instituições. Évora, principal centro urbano da região do Alentejo, foi historicamente um território agrário que passou por profundas transformações nas últimas quatro décadas: reforma agrária, êxodo rural e
71. Cf. Berliner; Istasse (2013).

72. Cf. Stello (2013).

73. Cf. Zanirato (2010) 
74. Fernandes (2016).

75. Ibid.

76. Sousa; Magalhães; Oliveira $(2005$, p. 87-97).

77. Cf. Fortuna (1997) crescimento da cidade extramuros. Soma-se a isso todo um processo de requalificação e planejamento urbano da área intramuros, hoje patrimônio mundial, promovido ainda nos anos 1980 pela primeira administração eleita. Abílio Fernandes, primeiro presidente da Câmara Municipal pós-Estado Novo, descreve da seguinte forma o início de sua administração:

encontramos um município do tempo do fascismo com muitos problemas na qualidade de vida das pessoas. Herdamos um território municipal com mais de 300 hectares que tinha o centro histórico muito antigo e na volta do centro histórico existiam bairros construídos recentemente, antes do 25 de abril, mas eram bairros todos eles clandestinos e onde vivia a maior parte da população de Évora [...]. Eram casas que não tinham rede de água, não tinham rede de esgotos, muitas delas não tinham eletricidade. Nós herdamos um território com muitos problemas de infraestruturas básicas. Portanto, a classificação de Évora como patrimônio mundial decorre de todo um processo de gestão autárquica de resolver primeiro os problemas das populações que tinham prioridade de melhorar as suas condições de vida. ${ }^{74}$

Tendo sido responsável pela administração municipal de Évora de 1977 até 2001, em sucessivas reeleições, o economista Abílio Fernandes destaca em sua fala o caráter participativo da comunidade nos anos 1980, salientando o perfil social das primeiras políiticas urbanas empreendidas no Centro Histórico e que levariam a candidatura à Unesco: "a nossa preocupação primeira não foi, portanto, patrimonial", mas "a de melhorar as condições de habitabilidade dos moradores do centro histórico". ${ }^{75} \bigcirc$ ex-dirigente destaca como importante política dos primeiros anos de sua administração o Plano Diretor de Évora de 1982, primeiro a ser publicado em Portugal e elemento central para a gestão do patrimônio cultural, dado que impulsionou a adaptação da estrutura administrativa municipal para tratar de questões diretamente ligadas ao campo do patrimônio cultural, com o Plano de Recuperação do Centro Histórico, o Plano de Circulação e Transportes, a criação do Núcleo do Centro Histórico, além de programas municipais de subsídios para a reabilitação e pintura de imóveis com valor histórico. ${ }^{76}$

A partir dos anos 1970 Évora testemunhou um processo de destradicionalização 77 por meio do qual o patrimônio foi deslocado do sentido que possuía no território, passando a ser determinado por sua dimensão metafórica, produto da competição estratégica por projeção da cidade em outros patamares e mercados. Na década seguinte, com a admissão de Évora na lista do patrimônio mundial, a administração local também passou a promover a cidade internacionalmente, criando redes de cooperação: 
depois da classificação nós realizávamos de dois em dois anos um encontro de quatro cidades classificadas como Patrimônio da Humanidade. [...] cada cidade que vinha à Évora trazia técnicos e urbanistas de recuperação do patrimônio e havia debates sobre essa matéria. Traziam gastronomia, traziam artesanato, traziam os políticos. [...] depois de três ou quatro encontros e dos debates, chegamos à conclusão de que a Unesco classificava as cidades, mas depois não dava nenhum apoio. Cada cidade ficava entregue a si própria. [...] e no último encontro saiu a proposta de transmitirmos à Unesco que deveríamos procurar criar uma associação das cidades patrimônio mundial. E foi realizado o encontro mundial da Unesco no Canadá em Toronto. Então, a Assembleia da Unesco pediu para que eu apresentasse a proposta. Então eu apresentei a proposta, as ideias-base e foi aprovada por unanimidade. E foi criada ali a Organização das Cidades Patrimônio Mundial. [...] organizamos um encontro em Fez, no Marrocos, e o terceiro encontro mundial foi em Évora em 1997.78

Carlos Fortuna ${ }^{79}$ entende que essas redes transnacionais movimentaram "um processo de simultânea mundialização do local e de localização do mundo, sinal incontestável da adaptação da cidade de Évora às novas tendências e exigências impostas pela globalização". Nesse sentido, foram instituídos mecanismos para o controle urbano, com a criação de zonas de preservação e de equipamentos para o desenvolvimento do turismo. Assim, as iniciativas que partiram da municipalidade catapultaram Évora a uma visibilidade internacional, mas também no contexto interno português. Em 1973 foi criado o Instituto Universitário de Évora, hoje Universidade de Évora, que, junto com o crescimento do fluxo turístico, contribuiu para as mudanças provocadas nas sociabilidades tradicionais. Conforme aponta o arquiteto responsável pelo Departamento do Centro Histórico, assim como os empreendimentos turísticos a Universidade promoveu a ocupação do Centro Histórico por jovens estudantes, com a adaptação de imóveis para pensionatos. A agitação provocada por bares e festas, advinda dessa ocupação volátil de jovens e estudantes, é motivo de reclamação por parte de famílias e moradores idosos. ${ }^{80}$

Outro exemplo dessas transformações é o Grupo Pró-Évora. A histórica organização civil voltada ao mecenato e à defesa do patrimônio segue atuando de maneira independente e se adaptou às mudanças. Outras demandas no que se refere ao patrimônio passaram a ser tema de discussão do grupo: excesso de turistas, perturbação causada pelos grupos de jovens turistas ou pela oscilante população de jovens universitários. O Pró-Évora, que possui sede própria em um edifício histórico, onde desenvolve atividades artísticas, exposições e encontros, assinou no ano de 2015 um protocolo para sediar um Centro Unesco para o Patrimônio Mundial, em parceria com outras entidades. A iniciativa será voltada para o trabalho com a comunidade, escolas e campanhas em defesa do patrimônio, conforme informações da direção do grupo. ${ }^{81}$
78. Cf. Fernandes, op. cit.

79. Fortuna, op. cit., p. 11.

80. Cf. Miranda (2016).

81. David (2016) 
82. Portugal (2006).

83. Conforme Sousa, Magalhães e Oliveira (2005, p. 28), entre 1940 e 2001 a população do Centro Histórico de Évora diminuiu em $70 \%$, ao contrário da população total da cidade, que cresceu cerca de $115 \%$ nesse mesmo período.

84. Portugal (2015b, p. 12).

85. Miranda (2016).

86. Portugal (2015a).

87. Fonseca (2005, p. 141).
A ocupação dos sítios, em particular do Centro Histórico de Évora, constitui um dos exemplos de tensionamento e frustrações que por vezes estão registrados nos discursos do poder público, apontando um processo de gentrificação que agrava os problemas sociais da cidade. A desertificação do Centro Histórico, abordada como resultado da declaração da cidade como patrimônio mundial, é qualificada como um problema, "uma facada nesse mesmo Centro Histórico", na fala de um representante do legislativo municipal. ${ }^{82} \bigcirc$ esvaziamento populacional da cidade muralhada avança desde os anos 1940,83 o que o estatuto de patrimônio mundial não conseguiu aplacar, convertendo-se na principal preocupação da administração municipal. ${ }^{84} \bigcirc$ envelhecimento da população que reside no Centro Histórico e questões relativas à habitabilidade de alguns edifícios protegidos são apontados pelo arquiteto encarregado do Departamento do Centro Histórico ${ }^{85}$ como os principais problemas a enfrentar nos próximos anos.

Da mesma forma, atas do Legislativo Municipal de Évora reportam limitações e contingenciamentos aos quais fica submetido o Centro Histórico, restringindo atividades econômicas informais, por exemplo. Reclamam os munícipes que, face ao desemprego reinante no país, a saída para um mercado constituído de mercadores ambulantes - que poderia atenuar a situação social de muitas famílias - é obstaculizada por não haver consentimento da Unesco. ${ }^{86}$

Em São Miguel das Missões, as mais de quatro décadas decorridas desde o tombamento federal até a candidatura à lista do patrimônio mundial foram de aprofundamento das políticas patrimoniais, com a aplicação de medidas protetivas do espaço físico do sítio histórico. No contexto brasileiro vivia-se o regime militar, época em que as políticas patrimoniais precisaram se enquadrar no modelo desenvolvimentista e nas mudanças provocadas pela industrialização crescente; nesse momento também ocorria intensa migração para os espaços urbanos. ${ }^{87}$

A maioria das ações implementadas nos anos 1960, 1970 e 1980 em São Miguel das Missões esteve voltada a consolidar as ruínas como monumento e a proteger a zona envolvente a fim de assegurar a integridade do bem cultural: o cemitério utilizado pela comunidade, ao lado das ruínas, foi realocado para outro espaço nos arredores da cidade; casas de populares foram desapropriadas e reinstaladas em outros terrenos pertencentes à municipalidade. Nesse período também ocorreu o cercamento do sítio e a ampliação do espaço de proteção, com a transferência de equipamentos de uso público até então situados nas imediações do parque, como uma escola, um clube social, um posto telefônico e outro da segurança pública. 
Algumas intervenções foram realizadas diretamente nas ruínas, conforme necessidades estruturais e posteriores ao desmoronamento de pedras das paredes do templo. No ano de 1978 técnicos do Iphan designados para uma visita técnica demonstravam que, além da restauração do monumento, havia o problema do loteamento e da ocupação dos terrenos no entorno das ruínas, e alertavam que "o monumento vale por si, mas muito mais também na medida em que ele estiver integrado a um contexto livre de elementos estranhos à antiga paisagem das Reduções". ${ }^{88}$ A preocupação expressa pelo arquiteto demonstra a forma como o instituto concebia a proteção naquele momento, entendendo o monumento como integrado ao espaço, porém distante da realidade urbana que afetava a vida das pessoas. A ocupação dos terrenos em São Miguel das Missões e o desenvolvimento da área urbana ocorreram durante o século XX, junto com as políticas patrimoniais que ampliaram progressivamente a área de proteção do sítio. ${ }^{89}$

No ano de 1980 foi implementado o Plano de Diretrizes para o Desenvolvimento Físico de São Miguel das Missões, através de projeto de lei aprovado pelos poderes da municipalidade de Santo Ângelo, porém com a intervenção direta dos técnicos do Iphan. A população se mostrava insatisfeita, como relata o então secretário municipal de turismo de Santo Ângelo, Mário Simon, designado a apresentar o Plano para a população:

não foi aceito o primeiro plano diretor, não foi. Tanto que eu acabei saindo meio corrido de lá, quando me pediram para apresentar. [...] porque tinha que retirar uma casa daqui, tinha que tirar outra lá, tinha que fazer uma rua lá, tinha que botar o colégio mais aonde, não sei o que, e aí a questão do tipo da casa para construir, o tipo dos prédios em volta, tudo isso tava previsto no plano. [...] e isso aí acabou com o sonho dos miguelinos. [...] eles me mandaram parar a apresentação e que fosse embora, que eles iam tratar esse assunto diretamente com a chefia do Iphan, e com quem fez o plano. E o plano foi feito pelo Iphan. Gente capacitada, engenheiros e urbanistas, e de acordo com as regras de proteção ao patrimônio. Mas com isso dá pra ver que eles não davam muita importância ao patrimônio..$^{90}$

A lei responsável por organizar o espaço urbano veio ao encontro do paradigma de desenvolvimento que priorizava o patrimônio cultural. A legislação limitou o uso do território por parte da população, causando inúmeros problemas e conflitos. Paradoxalmente, a população regional fortaleceu seus laços com o patrimônio ao longo do século XX. A proteção dos elementos materiais do passado jesuítico-guarani foi fundamental para a constituição de uma narrativa identitária fortemente marcada pela história missioneira, com inúmeras vertentes e para distintos propósitos. Foi-se buscar no passado idílico das reduções alguns valores e princípios que nortearam a forma como certos grupos se colocaram no espaço social do presente.
88. Fachada das Ruínas pode estar condenada (1978).

89. Em 1927 a intendência de Santo Ângelo procedeu à demarcação oficial dos terrenos em São Miguel e definiu a área do sítio em 8,6 hectares, demarcando a partir dele os terrenos ocupados e os disponíveis para venda pela municipalidade. Atualmente o sítio abrange um território de 38 hectares protegidos.

90. Simon (2015). 
91. Ibid.

92. Instituto do Patrimônio Histórico e Artístico Nacional (1983, p. 5).

93. Ibid., loc. cit.
O aceite da candidatura pelo Comitê da Unesco foi comemorado pela população de São Miguel e Santo Ângelo. Conforme o secretário,

foi uma grande festa [...] todo mundo se abraçava e a rádio anunciava. Ninguém sabia bem qual era o significado da importância disso. Mas eu me lembro de uma coisa que eu respondia: a partir dali, o Estado e o Iphan iam cuidar mais daquilo ali. la ter mais verba. ${ }^{91}$

O boletim do Iphan que noticiou o título de patrimônio mundial registrou também a declaração do prefeito de Santo Ângelo, na qual ele se comprometia a cumprir o Plano Diretor da Vila de São Miguel, proibindo a construção de imóveis no entorno da área protegida, e também a fala do secretário de turismo do Rio Grande do Sul em concordância com "a preocupação dos preservacionistas do patrimônio histórico de que é necessário conter o turismo predatório", realizando "um policiamento mais efetivo no parque missioneiro". ${ }^{92} \bigcirc$ superintendente do Iphan arrematava a seção da entrevista relembrando as responsabilidades da comunidade e da prefeitura em "honrar seus compromissos", bem como alertando que "a honra de ser Patrimônio da Humanidade pode ser cassada a qualquer momento, desde que a Unesco e seus técnicos constatem que não existe uma ação enérgica e constante pela preservação do local". ${ }^{93}$ Nessas declarações ficam perceptíveis os conflitos e fragilidades existentes nas relações entre representantes públicos dos entes federados responsáveis pela gestão do patrimônio - cujas falas destacam sobretudo responsabilidades, vigilância e compromissos que recaem sobre os administradores - e a população.

Não havia ainda, entre 1970 e 1980, uma política institucionalizada de inserção dos moradores nos espaços de decisão quanto ao patrimônio em São Miguel das Missões. No princípio do repovoamento, a escola, o cemitério, o clube, assim como casas de populares foram construídos nas proximidades das ruínas. Todos esses equipamentos foram realocados, não sem contendas e resistências por parte da população com a prefeitura de Santo Ângelo e com o Iphan. Essa readequação do espaço central da cidade se estendeu por décadas, pois somente no ano de 2015 foi inaugurada a nova igreja da comunidade de São Miguel das Missões, localizada a uma distância de um quilômetro do Parque Histórico, ao lado do salão paroquial, da escola e de uma praça. Readequações e ações, muitas delas hoje tidas como arbitrárias, por parte dos poderes públicos foram promovidas para salvaguardar e promover o patrimônio em São Miguel. Essa forma de ałuação, em certa medida, contribuiu para o afastamento das pessoas e tem hoje dificultado a inclusão e participação da população nos mecanismos democráticos. 
Porém, se o título de patrimônio mundial trouxe alguns conflitos de gestão do espaço envolvendo as famílias que repovoaram a localidade, também contribuiu para o processo de emancipação político-administrativa do município em 1988. movimento de moradores que visava à emancipação de São Miguel da cidade de Santo Ângelo, consoante ao fluxo nacional de emancipações municipais após a promulgação da Constituição de 1988,94 teve sua causa fortalecida pelo título de patrimônio mundial. Como pontua o secretário municipal de turismo da época, "a presença de turistas começou a despertar muito interesse de criar uma loja, um restaurante, uma casa de distribuição de artesanato [...] a promessa de desenvolvimento, de os recursos permanecerem na cidade". 95

Tanto em Évora como em São Miguel as zonas de preservação do entorno, ou zonas tampão, 96 são apontadas pelos arquitetos responsáveis como o ponto mais sensível e que acaba por gerar alguma instabilidade nas relações locais. Esse tema por um lado demonstra a compreensão alargada de patrimônio, concebendo cada vez mais a ambientação do bem cultural, sua relação com aquilo que o cerca, adentrando na compreensão de paisagem cultural; por outro, pode configurar elemento de fricção do patrimônio com a comunidade na qual se insere, tomando-se como exemplos os desalojamentos e as restrições impostas em razão da proteção ao bem patrimonial. Esse paradoxo não é novidade no campo da gestão patrimonial, mas segue como fator que impõe as maiores dificuldades para os profissionais responsáveis pela gestão diante das populações que vivem nessas localidades.

A tipologia do bem cultural também contribui para a gestão do espaço físico e influi na relação com as comunidades. Nos Centros Históricos há uma conexão direta com a vida das pessoas, uma vez que elas usam o patrimônio diariamente, ruas, praças, casas, o comércio, os equipamentos públicos ali existentes, diferente do que ocorre no caso de um parque histórico e arqueológico.

As "ruínas do povo de São Miguel" estão delimitadas por cercas de proteção no centro de uma pequena cidade, ela própria resultado de sucessivas rupturas provocadas por tratados e conflitos que remontam ao período colonial e imperial, até os esforços e conflitos de repovoamento vividos ao longo do século XX. ${ }^{97} \bigcirc$ avanço das políiticas de patrimônio foi ampliando a zona de proteção da área do parque. As mudanças de denominações - Ruínas de São Miguel, Sítio Histórico e Arqueológico e Parque Histórico Nacional - evidenciam o avanço de processos que são consequência de inúmeros estudos, mapeamentos, inventários e escavações arqueológicas. Todavia, mesmo não constituindo a tipologia de Centro Histórico, o patrimônio, no coração da cidade, convive com alguns problemas de gestão comuns, como os referentes à ocupação do solo, definição e aumento de zonas tampão, entre outras exigências que afetam diretamente a vida das pessoas do lugar.
94. Cf. Tomio (2005).

95. Simon, op. cit.

96. Artigos 103 a 107 das Orientações Técnicas para a Aplicação da Convenção do Patrimônio Mundial (Organização das Nações Unidas para a Educação, a Ciência e a Cultura, 2011).

97. Diversos documentos oficiais da administração municipal de Santo Ângelo e da Câmara de Vereadores, bem como notas da imprensa do final do século XIX até meados do século $\mathrm{XX}$ apontam problemas como posseiros, dificuldades na venda de terrenos pela administração municipal, além dos baixos índices de desenvolvimento econômico e humano do distrito de São Miguel, se comparado a outros distritos de Santo Ângelo nos anos 1920 e 1930. Cf. Relatórios dos intendentes... (s.d.) e Terrenos de S. Miguel e Santo Ângelo (1921). 
98. Brasil (1982, p. 9).

99. O reflexo dessas ações sobre o imaginário da população e os desafios para a gestão na atualidade são tema da dissertação de Silva (2009).

100. Seixas (2015).
Contudo, se existem problemas comuns, a forma de geri-los está submetida às estruturas de funcionamento da máquina pública de cada país. No caso brasileiro, o Iphan é a agência federal que detém a força reguladora maior nas questões do patrimônio, ocorrendo pouca divisão nas decisões entre outras instâncias, como estado e município. Essa centralização é também herança da trajetória de desenvolvimento das instituições públicas brasileiras, em que a força da União se sobrepõe às unidades federativas isoladas. Nesse contexto está o Iphan - um órgão que, por sua importância histórica nas políticas culturais brasileiras desde os anos 1930, foi continuamente reificado por muitos intelectuais e historiadores e segue sendo o órgão máximo e o fiel da balança nas causas relativas ao patrimônio cultural.

No relatório final da Comissão Parlamentar de Inquérito (CPI) destinada a investigar a situação do patrimônio histórico e artístico nacional, instalada na Câmara dos Deputados no ano de 1980, já era detectada a dissonância entre os entes federados no que se refere à preservação do patrimônio. A falta de prołagonismo dos municípios nos processos levou o relator da CPI sobre Cidades Históricas a destacar a seguinte sugestão de providência:

recomenda-se aos órgãos federais e estaduais da administração direta e indireta, maior entrosamento com as Prefeituras das Cidades Históricas, adotando, em relação às mesmas, procedimentos especiais, que levem em conta o interesse geral, a obrigação comum e a necessidade de preservar o patrimônio histórico e artístico nacional. ${ }^{98}$

Se levarmos em consideração o caso de São Miguel das Missões, desde aquela época pouco se fez para mudar esse panorama, o que é por si só um obstáculo para as tentativas de transversalidade da gestão integrada dos bens culturais, uma vez que se torna um fator de distanciamento entre as comunidades locais e o patrimônio. Em São Miguel das Missões até mesmo os gestores responsáveis pelas políticas atuais de patrimônio vivenciam essa realidade, pois enfrentam resistências e dificuldades na promoção de estratégias integradas e horizontais de proteção, devido à forma como as políticas foram conduzidas anteriormente. ${ }^{99}$ Conforme reconhece uma das arquitetas do Iphan responsáveis pela gestão do Parque em São Miguel, "a ação do Iphan foi por um tempo um tanto quanto autoritária e era a maneira que se tinha para conservar o sítio. Se não fosse isso não teria o sítio da forma como se tem ele hoje, mas foi uma coisa que foi mudando ao longo do tempo". ${ }^{100}$ Audiências públicas, de iniciativa e coordenação do Iphan, assim como a nomeação, em 2014, de uma arquiteta natural na localidade para chefiar o escritório do órgão federal em São Miguel, 
demonstram algumas das tentativas de mudanças graduais e deixam transparecer também as dificuldades impostas pelo histórico da gestão do patrimônio no Brasil.

A superação disso não é simples, pois todo esse histórico da centralidade da governança do patrimônio criou uma via de mão dupla. Se por um lado o Iphan salvaguardou importantes elementos materiais que se estivessem sob a guarda das municipalidades talvez não mais existissem, por outro se constituiu como o órgão supremo de decisão para a preservação do patrimônio nacional ao longo do século XX. Tal supremacia acabou contribuindo também, nas cidades patrimonializadas, para a criação de uma geração de cidadãos que se distanciou de suas responsabilidades para com o patrimônio. Assim, a população aprendeu a delegar somente ao Iphan as tarefas de preservação e, de maneira ambígua, acaba por culpabilizar o órgão, seja quando ele é obrigado a interferir na propriedade privada, seja nos momentos em que ele deixa a desejar na conservação do patrimônio.

Um dos aspectos que se contrapõem à maneira como as políticas de patrimônio têm sido implementadas no Brasil, não somente observando o contraste com o Centro Histórico de Évora, mas no contexto português como um todo, referese à maior autonomia e responsabilidade dos municípios na preservação de seus patrimônios. No formato brasileiro, o lphan, enquanto agência federal responsável pela proteção, atua com escritórios nas cidades que são patrimônio mundial. Já em Évora, a maior parte das responsabilidades para a manutenção do título, com todas as vantagens e problemas que ele acarreta para a população local, recai sobre a municipalidade, em um órgão específico da Câmara Municipal, o Departamento do Centro Histórico. No contato com responsáveis pela gestão do patrimônio português em diferentes níveis (local, nacional e Unesco Portugal), percebe-se que o papel do governo nacional, através da Direção Geral do Patrimônio Cultural (DGPC), é bastante reduzido se comparado ao das câmaras municipais, que podem decidir, fiscalizar e até mesmo realizar inventários e apresentar candidaturas à Unesco. ${ }^{101}$ A própria candidatura de Évora para a Unesco foi preparada por funcionários municipais e acompanhada de perto pelos representantes do poder público, a partir de toda a documentação levantada anteriormente para a gestão local do patrimônio. ${ }^{102}$ No caso de São Miguel, a candidatura foi organizada sem a participação de agentes locais, conforme afirma o secretário de turismo da época, para quem a documentação "vinha pronta do Iphan e o prefeito só assinava". 103

Portugal e Brasil viviam os efeitos de um contexto mundial de rápidos avanços tecnológicos, desruralização e crescimento urbano nos anos 1970 e 1980. Entretanto, as realidades políticas, econômicas e culturais de cada país
101. O setor de turismo corresponde a cerca de $6,5 \%$ do Produto Interno Bruto português e está em crescimento desde os anos 1960. O Plano Estratégico Nacional de Turismo (2006-2015) tem contribuído para o investimento, desenvolvimento e diversificação do setor (cf. Daniel, 2010). As políticas patrimoniais estão inseridas nesse contexto estratégico de desenvolvimento do mercado turístico.

102. Fernandes, op. cit. 103. Simon, op. cit. 
104. Fabre; Iuso (2009, p. 24).

105. Ibid., loc. cit. apresentavam particularidades. Enquanto Portugal saía de um longo regime ditatorial, o Brasil vivia imerso em regime militar. $\bigcirc$ tratamento dado ao patrimônio nacional em cada país correspondia a estruturas de organização bastante particulares, que expressavam a trajetória interna da constituição de cada Estado. Essas estruturas precisaram se adaptar, tanto no que se refere aos discursos como às estratégias práticas de gestão, a fim de cumprir as exigências de um órgão internacional quando da apresentação de candidaturas ao patrimônio mundial. Assim, se por um lado o patrimônio mundial permitiu projetar os referenciais culturais dos países, por outro, fez com que cada nação confrontasse suas realidades e dificuldades internas no trato com o patrimônio.

A inscrição na lista mundial pressupõe a garantia de uma visibilidade permanente ao monumento, concorrendo para tanto "presenças humanas e materiais". ${ }^{104}$ Ao mesmo tempo, transforma o lugar ao delimitar uma zona qualificada pela autoridade patrimonial e submetida a um regime jurídico e administrativo diferente do restante do contexto no qual se inscreve, imprimindo um caráter de unanimidade que garanta a continuidade da empresa patrimonial e omitindo clivagens, como as necessidades e expectativas das populações locais, "os que habitam os monumentos", na expressão de Daniel Fabre e Anna luso. ${ }^{105}$

\section{CONSIDERAÇÕES FINAIS}

Diferentes contextos históricos definem o patrimônio de Évora e São Miguel, continentes distintos: de um lado, expressões de uma história milenar; de outro, testemunhos materiais do período colonial. As consequências advindas das constituições históricas dessas cidades compõem também as bases das narrativas patrimoniais que dão sentido à preservação e a consagração desses bens como patrimônios nacionais e mundiais.

Em Évora, o patrimônio mundial representou mais uma distinção à cidade que possuía uma estrutura político-administrativa secularmente consolidada. Em São Miguel, a inscrição na lista do patrimônio mundial catapultou a localidade ao status de município, obtendo sua emancipação político-administrativa. Assim, entra em campo a própria constituição administrativa da estrutura estatal. Em Portugal, tem-se um municipalismo robusto, onde o parlamento representa a força principal da república, o que se estende às câmaras municipais. No Brasil, o poder está centralizado na federação, e os municípios têm seus poderes reduzidos perante os órgãos federais. 
Não queremos dizer, todavia, que uma gestão do sítio de São Miguel colocada inteiramente nas mãos do município seria mais eficiente e mais próxima da população local. Uma série de outros elementos precisariam ser avaliados para sustentar essa afirmação, uma vez que há também uma cultura administrativa secular concebida dessa forma. Porém, o compartilhamento das reponsabilidades sobre a preservação de maneira mais efetiva entre os entes federativos poderia, apesar de todas as contradições existentes, aproximar a comunidade das políticas de preservação e consequentemente fortalecer seus laços com o patrimônio, o que é possível observar mesmo com os habituais ruídos dos espaços patrimoniais, no caso do Centro Histórico de Évora.

A instauração de uma política global pela lista da Unesco configurou um paradoxo: se por um lado busca reconhecer a importância singular desses lugares para a humanidade, instituindo padrões de organização que garantam sua preservação, por outro lado muitas dessas políticas não se aplicaram da mesma forma nos diferentes lugares e não obtiveram os êxitos desejados. Isso ocorre justamente devido aos contextos históricos, às formações sociais e urbanas de cada localidade e principalmente às estruturas dos poderes públicos em cada Estado, muitas vezes pouco consideradas pelas instâncias internacionais ou não enfrentadas abertamente pelos Estados que apresentam as candidaturas. 


\section{REFERÊNCIAS}

FONTES IMPRESSAS

CORRESPONDÊNCIAS de Rodrigo Melo Franco de Andrade para Augusto Meyer. Rio de Janeiro: Fundação Casa de Rui Barbosa, [193-].

FACHADA das Ruínas pode estar condenada. A Tribuna Regional, Santo Ângelo, n. 821, Última Página, 6 dez. 1978.

INSTITUTO DO PATRIMÔNIO HISTÓRICO E ARTÍSTICO NACIONAL. Boletim do SPHAN, $\mathrm{n}$. 27, nov./dez. 1983.

LEIS Orçamentárias do município exercícios de 1901-1927. Santo Ângelo, 1901-1927. (Arquivo Histórico Municipal Augusto César Pereira dos Santos).

OFÍCIO de Rodrigo Melo Franco Andrade ao Ministro da Educação, Gustavo Capanema. Rio de Janeiro: Fundação Casa de Rui Barbosa, 29 set. 1937.

RELATÓRIO da Secretaria de Obras Públicas. Porto Alegre: Officinas Graphicas d'A Federação, 1926. (Assembleia Legislativa do Rio Grande do Sul, Acervo Memorial).

RELATÓRIOS dos Intendentes de Santo Ângelo. Secção Intendendência, [s.d.]. cx. 20. (Arquivo Histórico Municipal de Santo Ângelo).

TERRENOS DE S. Miguel e São João. A semana, Santo Ângelo, n. 82, p. 1, 24 fev. 1921. (Acervo Histórico Municipal Augusto César Pereira dos Santos, 1901-1927).

LIVROS, ARTIGOS E TESES

ALMEIDA, Carmen et al. Riscos de um século: memórias da evolução urbana de Évora. Évora: Sociedade Tipográfica, 2001. 
BERLINER, David; ISTASSE, Manon. Les hyper-lieux du patrimoine mondial. Gradhiva, Paris, v. 18, n. 2, p. 124-145, 2013.

BRASIL. Câmara dos Deputados. Comissão Parlamentar de Inquérito destinada a investigar a situação do Patrimônio Histórico e Artístico Nacional e avaliar a política do governo federal para sua defesa e conservação. Projeto de Resolução 304/1982: relatório e conclusões. Brasília, 1982.

CÁTEDRA, María. Évora: los mitos de origen de una ciudad. A cidade de Évora, Évora, série 2, n. 7, p. 423-445, 2009.

La reconstrucción de una ciudad: la restauración del Templo de Diana de Évora. Revista de Antropología Social, Curitiba, n. 20, p. 309-328, 2011.

CHOAY, Françoise. As questões do patrimônio: antologia para um combate. Lisboa: Edições 70, 2011.

CHUVA, Márcia. Os arquitetos da memória: sociogênese das práticas de preservação do patrimônio cultural no Brasil (anos 1930-1940). Rio de Janeito: Editora UFRJ, 2009.

COMISSÃO NACIONAL DA UNESCO. 30 anos de boas práticas: Portugal e o Património Mundial. Lisboa: Ministério dos Negócios Estrangeiros, 2014.

COSTA, Lúcio; PESSÔA, José. Lucio Costa: documentos de trabalho. Brasília: Iphan, Ministério da Cultura, 1998.

CUNHA, Luis M. de J. A Nação nas malhas da sua identidade: o Estado Novo e a construção da identidade nacional. Braga: Universidade do Minho/Instituto de Ciências Sociais, 1994.

CUSTÓDIO, Jorge. Os “Amigos dos Monumentos" e o elitismo patrimonial. In: (Org.). 100 Anos de Património: Memória e Identidade (Portugal 1910-2010). Lisboa: Instituto do Património Arquitetónico e Arqueológico, 2010. p. 57-62.

DANIEL, Ana Cristina Marques. Caracterização do sector turístico em Portugal. Tékhne, Barcelos, n. 14, p. 255-276, 2010.

D'ENCARNAÇÃO, José. André de Resende, epigrafista. In: CONGRESSO INTERNACIONAL DO HUMANISMO PORTUGUÊS, 1., 2002, Coimbra-Lisboa-Évora. Anais... Lisboa: Centro de Estudos Clássicos, 2002. p. 305-310. 
D'ENCARNAÇÃO, José. Sertório, general romano: guerrilheiro e mito? In: SEMINÁRIO MEMÓRIA, MITO E HISTÓRIA: O SACRIFÍCIO DE ALMEIDA, 1., 2008, Almeida, Actas... Almeida: Centro de Estudos de Arquitetura Militar, 2009. p. 99-105.

FABRE, Daniel; IUSO, Anna. Les monuments sont habités. Paris: Éditions de la Maison des Sciences de L'homme, 2009.

FONSECA, Maria Cecília Londres. O patrimônio em processo: trajetória da política federal de preservação no Brasil. Rio de Janeiro: Editora UFRJ/Minc-Iphan, 2005.

FORTUNA, Carlos. Destradicionalização e imagem da cidade: o caso de Évora. In: (Org.). Cidade, cultura e globalização. Oeiras: Celta, 1997. p. 231-257.

FRANCO, António. Évora ilustrada. Nazareth, 1945.

GONÇALVES, José Reginaldo Santos. A retórica da perda: os discursos do patrimônio cultural no Brasil. Rio de Janeiro: Editora UFRJ, 1996.

HAFSTEIN, Valdimar. Claiming Culture: Intangible Heritage Inc., Folklore@, Traditional Knowledge $^{\mathrm{TM}}$. In: HEMME, Dorothee; TAUSCHEK, Markus; BENDIX, Regina (Eds.). Prädikat Heritage: Wertschöpfungen aus kulturellen Ressourcen. Münster: Studien zur Kulturanthropologie/Europäischen Ethnologie, 2007. p. 75-100. v. 1.

HALL, Stuart. A centralidade da cultura: notas sobre as revoluções culturais do nosso tempo. Educação E Realidade, Porto Alegre, v. 22, n. 2, p. 15-46, 1997.

HARNISCH, Wolfgang Hoffmann. O Rio Grande do Sul: a terra e o homem. 2. ed. Porto Alegre: Globo, 1952.

HARRISON, Rodney. Heritage: critical approaches. New York: Routledge, 2013.

JADÉ, Mariannick. Enjeux et perspectives d'un fait patrimonial en devenir. 2009. 219 f. Tese (Doutorado em Museologia) - Muséum National D'histoire Naturelle, Paris, 2009.

LAMEgO, Alberto. Os Sete Povos da Missões. Revista do Serviço do Patrimônio Histórico e Artístico Nacional, Rio de Janeiro, n. 4, p. 55-81, 1940.

LENIAUD, Jean-Michel. Les Archipels du passé: le patrimoine et son histoire. Paris: Fayard, 2002. 
MARCHI, Darlan de M.; FERREIRA, Maria L. M. O espetáculo do patrimônio: o som e luz em São Miguel das Missões, Brasil. In: MUÑOZ, Jenny González (Org.). Desafíos y propuestas en salvaguarda de nuestro patrimonio cultural. Caracas: Fondo Editorial de la Universidad Latinoamericana y del Caribe, 2016. p. 223-241.

MARCOTTE, Pascale; BOURDEAU, Laurent. La promotion des sites du Patrimoine mondial de l'Unesco: compatible avec le développement durable? Management E Avenir, Liège, v. 34, n. 4, p. 270-288, 2010.

MEIRA, Ana Lúcia Goelzer. O patrimônio histórico e artístico nacional no Rio Grande do Sul no século $X X$ : atribuição de valores e critérios de intervenção. 2008. 483 f. Tese (Doutorado em Planejamento Urbano e Regional) - Universidade Federal do Rio Grande do Sul, Porto Alegre, 2008.

MIRANDA, Eduardo. Évora 20 Anos de Patrimônio Mundial - Um Balanço: contributo para a avaliação do impacto da classificação na cidade. A cidade de Évora, Évora, série 2, n. 7, p. 23-43, 2009.

PEIXOTO, Paulo. A corrida ao status de Patrimônio Mundial e o mercado urbano de lazer e turismo. Veredas, Rio de Janeiro, ano 1, n. 1, p. 23-45, 2002.

PESAVENTO, Sandra Jatahy. Missões, um espaço no tempo: paisagem da memória. In: PESAVENTO, Sandra Jatahy; GOELZER, Ana Lúcia (Orgs.). Fronteiras do mundo ibérico: patrimônio, território e memória das Missões. Porto Alegre: Editora da UFRGS, 2007. p. 51-63.

PORTUGAL. Câmara Municipal de Évora. Plano de Gestão do Centro Histórico de Évora. Évora: Departamento do Centro Histórico, Património e Cultura, 2013.

PRATS, Llorenç. El concepto de patrimonio cultural. Política y Sociedad, Madrid, v. 27, p. 6376, 1998.

ROSAS, Lúcia. A gênese dos monumentos em Portugal. In: CUSTÓDIO, Jorge Raimundo (Org.). 100 Anos de Património: memória e identidade (Portugal 1910-2010). Lisboa: Instituto do Património Arquitetónico e Arqueológico, 2010. p. 41-46.

RODRIGUES, Marcial A. E. 80 aniversário do Grupo Pró-Évora: um desafio à história local. In: GRUPO PRÓ-ÉVORA. Catálogo exposição comemorativa (1919-1999 - 80 anos): patrimônio artístico e documental. Évora: Imprimévora, 1999. p. 5-12.

RODRIGUES, Paulo Simões; MATOS, Ana Cardoso. Restaurar para renovar na Évora do século XIX. Monumentos, Lisboa, n. 26, p. 134-143, 2007. 
SCIFONI, Simone. Patrimônio mundial: do ideal humanista à utopia de uma nova civilização. GeoUSP, São Paulo, n. 14, p. 77-88, 2003.

SILVA, Joaquim Palminha. Monografia Freguesia da Sé e São Pedro: subsídios monográficos. Évora: Junta de Freguesia da Sé e São Pedro, 2011.

SILVA, Willians Fausto. Patrimônio a contragosto: a presença de bens culturais na vida cotidiana de São Miguel das Missões/RS. 2009. 99 f. Dissertação (Mestrado em Museologia e Patrimônio) - Universidade Federal do Estado do Rio de Janeiro, Rio de Janeiro, 2009.

SOUSA, Ana Rita; MAGALHÃES, Andréia; OLIVEIRA, Maria M. Estudo sobre o despovoamento dos Centros Históricos da Rede Atlante: Porto, Guimarães, Angra do Heroísmo, Évora, Santiago de Compostela e Lugo. Évora: Câmara Municipal de Évora, 2005.

STELLO, Vladimir Fernando. Sítio arqueológico de São Miguel Arcanjo: avaliação conceitual das intervenções 1925-1927 e 1938-1940. 2005. 177 f. Dissertação (Mestrado em Engenharia Civil) - Universidade Federal do Rio Grande do Sul, Porto Alegre, 2005. 177 p.

Além das reduções: a paisagem cultural da região missioneira. 2013. 239 f. Tese (Doutorado em Planejamento Urbano e Regional) - Universidade Federal do Rio Grande do Sul, Porto Alegre, 2013.

TOMIO, Fabrício Ricardo de Limas. Federalismo, municípios e decisões legislativas: a criação de municípios no Rio Grande do Sul. Revista de Sociologia e Política, Curitiba, n. 24, p. 123-271, 2005.

VASCONCELOS, Diogo Mendes. Vida de Lúcio André de Resende. In: RESENDE, André. As antiguidades da Lusitânia. Lisboa: Fundação Calouste Gulbenkian, 1996. p. 10-56.

WBATUBA, Berenice B. Rossner et al. (Org.). Plano estratégico de desenvolvimento da região das Missões. Santo Ângelo: FuRI, 2017.

WILliAMS, Daryle. Além da História-Pátria: as missões jesuítico-guaranis, o Patrimônio da Humanidade e ou $\neg$ tras histórias. Revista do Patrimônio Histórico e Artístico Nacional, Brasília, n. 34, p. 281-301, 2012.

YAN, Haiming. World Heritage as discourse: knowledge, discipline and dissonance in Fujian Tulou sites. International Journal of Heritage Studies, Abingdon, v. 21, n. 1, p. 65-80, 2015.

ZANIRATO, Silvia Helena. Patrimônio da Humanidade: controvérsias conceituais e legais na definição de bem comum. In: ENCONTRO NACIONAL DA ANPPAS, 5., 2010, Florianópolis. Anais eletrônicos... Florianópolis: UFRGS, 2010. Disponível em: <https://bit.ly/2P3hhGC>. Acesso em: 24 ago. 2018. 
ESPETÁCULO Som e Luz. Espetáculo Som e Luz, São Miguel das Missões, 2015. Facebook. Disponível em: <https://bit.ly/2wonOnD>. Acesso em: 24 ago. 2018.

INSTITUTO NACIONAL DE ESTATÍSTICA. Anuário estatístico da região do Alentejo 2016. Lisboa, 2017. Disponível em: <https://bit.ly/2Mu1X8V>. Acesso em: 24 ago. 2018.

ORGANIZAÇÃO DAS NAÇÕES UNIDAS PARA A EDUCAÇÃO, A CIÊNCIA E A CULTURA. Jesuit Missions of the Guaranis: San Ignacio Mini, Santa Ana, Nuestra Señora de Loreto and Santa Maria Mayor (Argentina), Ruins of Sao Miguel das Missoes (Brazil). Paris, 1983. Disponível em: <https://bit.ly/2o4ynIG>. Acesso em: 24 ago. 2018.

. Report of the 8th Session of the committee. Buenos Aires: World Heritage Committee, 2 nov. 1984. Disponível em: <https://bit.ly/2wbp2mO>. Acesso em: 24 ago. 2018.

Historic Centre of Évora. Paris, 1986. Disponível em: <https://bit.ly/2Mz4zCq >. Acesso em: 24 ago. 2018.

World Heritage List. Paris, 16 nov. 2005. Disponível em: <https://bit.ly/1mxm7f3>. Acesso em: 24 ago. 2018.

Orientações Técnicas para a Aplicação da Convenção do Patrimônio Mundial, Lisboa: Centro do Património Mundial, 2011. Disponível em: <https://bit.ly/2o6v2Zr> Acesso em: 24 ago. 2018.

. Candidatura a património mundial da Universidade de Coimbra Alta e Sofia. Coimbra, 2013. Disponível em: <https://bit.ly/2OYLZR5>. Acesso em: 24 ago. 2018.

PORTUGAL. Câmara Municipal de Évora. Acta $n^{\circ} 11$ da reunião ordinária da Câmara Municipal de Évora. 9 maio 2006. Disponível em: <https://bit.ly/2BIUkGH>. Acesso em: 24 ago. 2018.

Acta $n^{\circ} 08$ da reunião ordinária da Câmara de Évora. 15 abr. 2015a. Disponível em: $<$ https://bit.ly/2o7nKol>. Acesso em: 24 ago. 2018.

. Proposta de delimitação da Área de Reabilitação Urbana do Centro Histórico de Évora. Évora, 2015b. Disponível em: <https://bit.ly/2Mu3qfq>. Acesso em: 24 ago. 2018. 


\section{ENTREVISTAS}

DAVID, Celestino. Entrevista [21 set. 2016]. Entrevistador: Darlan de Mamann Marchi. Évora, 2016.

FERNANDES, Abílio. Entrevista [9 set. 2016]. Entrevistador: Darlan de Mamann Marchi. Évora, 2016.

MIRANDA, Eduardo. Entrevista [21 set. 2016]. Entrevistador: Darlan de Mamann Marchi. Évora, 2016.

SEIXAS, Ana L. Entrevista [10 fev. 2015]. Entrevistador: Darlan de Mamann Marchi. São Miguel das Missões, 2015.

SIMON, Mário. Entrevista [25 fev. 2015]. Entrevistador: Darlan de Mamann Marchi. Santo Ângelo, 2015.

Artigo apresentado em 05/09/2017. Aprovado em 20/04/2018.

\section{(cc) BY}

All the contents of this journal, except where otherwise noted, is licensed under a Creative Commons Attribution License 